\title{
The Roles of Cellular Nanomechanics in Cancer
}

\author{
Murali M. Yallapu ${ }^{1}$, Kalpana S. Katti ${ }^{2}$, Dinesh R. Katti ${ }^{2}$, Sanjay R. Mishra ${ }^{3}$, Sheema Khan ${ }^{1}$, \\ Meena Jaggi ${ }^{1}$, and Subhash C. Chauhan ${ }^{1}$ \\ ${ }^{1}$ Department of Pharmaceutical Sciences and Center for Cancer Research, College of Pharmacy, \\ University of Tennessee Health Science Center, Memphis, Tennessee 38163 \\ ${ }^{2}$ Department of Civil and Environmental Engineering, College of Engineering, North Dakota State \\ University, Fargo, North Dakota 58105 \\ ${ }^{3}$ Department of Physics, University of Memphis, Tennessee 38152
}

\section{Abstract}

The biomechanical properties of cells and tissues may be instrumental in increasing our understanding of cellular behavior and cellular manifestations of diseases such as cancer. Nanomechanical properties can offer clinical translation of therapies beyond what are currently employed. Nanomechanical properties, often measured by nanoindentation methods using atomic force microscopy, may identify morphological variations, cellular binding forces, and surface adhesion behaviors that efficiently differentiate normal cells and cancer cells. The aim of this review is to examine current research involving the general use of atomic force microscopy/ nanoindentation in measuring cellular nanomechanics; various factors and instrumental conditions that influence the nanomechanical properties of cells; and implementation of nanoindentation methods to distinguish cancer cells from normal cells or tissues. Applying these fundamental nanomechanical properties to current discoveries in clinical treatment may result in greater efficiency in diagnosis, treatment, and prevention of cancer, which ultimately can change the lives of patients.

\section{Keywords}

atomic force microscopy; cellular elasticity; cancer therapeutics; cellular mechanics; nanomechanical properties; cancer cells; anticancer drugs

\section{INTRODUCTION}

Cancer remains the second leading cause of death worldwide. ${ }^{1}$ The American Cancer Society reports $\sim 1,660,290$ new cancer cases and $\sim 580,350$ cancer-related deaths occurred during 2013 in the United States alone. ${ }^{2}$ In our opinion, it is important to develop

(C) 2014 Wiley Periodicals, Inc.

Correspondence to: Prof. Subhash C. Chauhan, Cancer Research Building, University of Tennessee Health Science Center, 19 South Manassas, Memphis, TN 38163-0001. schauha1@uthsc.edu. Dr. Murali M. Yallapu, Cancer Research Building, University of Tennessee Health Science Center, 19 South Manassas, Memphis, TN 38163-0001. myallapu@uthsc.edu. 
methodologies that improve understanding of disease condition and progression.

Physicochemical forces drive proliferation, differentiation, and migration of cells in living tissue. Significant alteration of these forces or heterogeneity within the tissue implicates a role of nanomechanics in cancer diagnosis. Biomechanical or nanomechanical properties (nanomechanics) of ultracellular and subcellular components may provide the indications regarding onset and progression of carcinogenesis. Using scanning force microscopy, Lekka et al. ${ }^{3}$ initially studied the elastic properties of cells and determined that normal (Hu609 and HCV29) cells have a higher magnitude of Young's modulus than cancerous (Hu456, T24, BC3726) cells. Similarly, the elasticity function of cells distinguishes different cells using a microfluidic optical stretcher. ${ }^{4}$ Atomic force microscopy (AFM) has evolved into a multifaceted tool that can efficiently differentiate normal and cancer cells at a nanoscale level. Now these nanomechanical properties have significant implications in cancer research, including in cancer therapeutics. ${ }^{5-8}$ The measure of elastic behavior of the ultrastructural network of cells has also led to the development of drug molecules for cancer therapeutics, which is an attractive area of research in the pharmaceutical industry. ${ }^{9}$ Therefore, the aim of this review is to (1) outline the importance of AFM for measuring cellular nanomechanics and the factors that influence the measurements, (2) characterize the transformation of normal cells to cancer cells to metastasis, (3) examine the implications of indentation of nanoscale mechanics in cancer treatment, diagnosis, and therapeutics, and (4) assess the clinical validation of nanomechanics. This review also gives insight into evaluating the nanomechanics of cells and extrapolating for the estimation of carcinogenesis.

\section{AFM AND CELLULAR NANOMECHANICS}

The current review summarizes recent studies that link transformation of normal cells to cancer cells using nanomechanical properties of cells. The nanoscale measurements can be performed by employing various types of analytical techniques such as micropipette aspiration (typical force range, 1-100 nN), optical tweezers/optical traps $(1-500 \mathrm{pN})$, magnetic bead microrheology (twisting, $10 \mathrm{pN}$ to $1 \mathrm{nN}$; pulling, $100 \mathrm{pN}$ to $10 \mathrm{nN}$ ), AFM (10 pN to $100 \mathrm{nN}$ ), shear flow (1-100 Pa), microindenter (1-100 nN), and so on. ${ }^{10,11}$ In cell biology, typical force ranges are 1-10 pN in the case of kinesin and myosin, $\sim 1-200 \mathrm{pN}$ for protein-protein interactions, $\sim 100 \mathrm{pN}$ for partial protein unfolding, and $\sim 1 \mathrm{nN}$ to $10 \beta \mathrm{N}$ for migrating or contracting cells. ${ }^{11}$ In many cases, the nanoscale mechanical measurements are related to the indentation and compression behavior of cells, which determine their overall consolidated ultra- to nanoscopic structures. AFM is widely used to investigate cell morphology through imaging and mechanical measurements in deflection control (Fig. 1A). 5, 6, 12 AFM force spectroscopy experiments can measure deflection of the cantilever versus sample position, from which tip-sample interaction is determined. AFM force-based spectroscopy is used for molecular recognition mapping, single molecule force spectroscopy, and single-cell force spectroscopy to reveal the localized interactions of biological molecules at a single molecular level. From these distinct measurements, it may be possible to differentiate between malignant and nonmalignant mammalian cells. ${ }^{13}$ Cell height, surface roughness, nucleus morphology, cytoplasm area, microtubule networks, fibril 
area, stiffness, and Young's modulus are commonly investigated components that reveal the nature of investigative cells.

AFM nanoindentation is capable of capturing time-evolved mechanical responses from structurally varied biological proteins, sugars, mineralized hard and soft tissues, and very complex composite tissues. ${ }^{14,15}$ Nanoindentation techniques have been employed to study microbial, ${ }^{16}$ stem cells, ${ }^{17}$ brain, ${ }^{18}$ dental, and bone, ${ }^{19-22}$ other biological hard tissues such as seashells, ${ }^{23}, 24$ aging, and other diseases. The use of AFM to examine various aspects of cell(s), tissue(s), and cancer has been reported in detail (Fig. 1B). However, studies of nanoindentation or nanomechanics in cancer research are limited; therefore, significant opportunity exists to implement this technique. Nanoindentation studies on biological tissues conducted over the last decade suggest significant promise in the use of nanomechanics to differentiate cancer cells and normal cells. With improved technologies, nanoindentation techniques combined with in situ imaging capabilities provide new opportunities in cancer research. Significant research efforts directed toward experimental as well as modeling have been conducted to examine physicomechanical mechanisms of cellular functions including differentiation, growth, migration, and death. ${ }^{25}$ The mechanical properties of all these stages of cells distinctly vary. ${ }^{25}$ Such nanomechanical cellular information enhances our understanding regarding the complexity of cancer at the cellular and tissue level and thus can lead to development of advanced clinical solutions.

\section{NANOINDENTATION FUNCTION AND FACTORS AFFECTING MECHANICAL PROPERTIES}

A recent review article describes in detail the use of nanoindentation and its function, appropriate mechanical models used to test the indentation measurements at given test conditions, and suitable types of tip geometries helpful to measure indentations specifically on living cells. ${ }^{26}$ In this section, we provide detailed information on conventional use of nanoindentation, function of nanoindentation, typical mechanical models used, and various factors that influence measurements.

\subsection{Use of Nanoindentation}

Nanoindentation has primarily been used to characterize ultrastructure and mechanical properties of inorganic stiff/hard materials such as metals at small scales. ${ }^{27}$ Experimental nanoindentation studies enable monitoring of materials' discrete events such as plasticity, creep parameters, shear instability, phase transformation, crack, and delamination. ${ }^{7,} 25$ These measurements can be accomplished by determining the relaxation of the sample under load. The analysis examines the displacement of the indent just before the relaxation at a predetermined time, which is always much shorter than the characteristic relaxation time of the material. In biomedical sciences, it has been widely used to map and understand the gel structures in the human body to identify advanced poroelasticity. Cells or biological tissues consist of dynamically deformable rheology that is highly complex, rendering evaluation of nanomechanical behavior that is much involved. ${ }^{28}$ 


\subsection{Function of Nanoindentation}

Typically, nanoindentation experiments involve recording force-displacement curves of cells under load-controlled or displacement-controlled modes (Fig. 2). The forcedisplacement curve (e.g., Fig. 2B) is converted to the force-indentation curve (e.g., Fig. 2C), which directly depicts the stiffness of the cell surface. The Hertzian model is frequently used to generate the quantitative data on the Young's modulus $(E)$ of the cell surface (i.e., elastic modulus, $E$ ). Most of the force-displacement measurements unveil the inter- and intramolecular forces of cell-cell and cell-surface bimolecular associations. ${ }^{29}$ This methodology is used to obtain a force-displacement curve in a three-step process: (i) approach: AFM probe/tip brought close to the cellular surface, (ii) contact or indent (compression step): indentation into the cell surface provides interaction between the cellsurface proteins and the tip, and (iii) retraction or separation (decompression step): retraction/separation from the surface of the cell allows extension of the bound macromolecule(s) as the tip-cell distance. ${ }^{30}$ Nanoindentation data are highly influenced by the tip/cantilever type, substrate, mechanical model used, and in vitro/in vivo physiological condition. ${ }^{11,26,31}$ A spherical indenter is recommended for biological tissues/cells to enable small stress concentrations, while a sharp tip indenter suits relatively hard materials including dental and bone samples. ${ }^{28,29}$ A pyramidal tip can be used for determining nanoscale mechanical properties of living cells. ${ }^{32,33} \mathrm{Few}$ reviews have been published that describe the mechanisms of indentation on hard materials and hard tissues $25,34,35$ and a comprehensive review at the cellular level with prospective cancer applications is not available.

\subsection{Models Used to Measure Nanomechanics}

Nanoindentation data are usually described in the form of Young's moduli or the equilibrium elastic modulus, which is calculated by converting force-displacement curves into force-indentation curves and fitting with the Hertz model. ${ }^{36-38}$ The appropriate Poisson ratio and half opening angle of the tip for cells and tissue samples are approximately $0.5^{\circ}$ and $36^{\circ}$, respectively. However, in this model, measurements have been restricted to low force ranges resulting in $<500 \mathrm{~nm}$ surface indentations in order to avoid cellular surface destruction. Many earlier studies have utilized the Hertz model for indentation on living cells, but living cell components such as cytoplasm/membrane/cytoskeleton structure often do not exhibit a linearly elastic behavior as approximated under Hertzian theory. Chen and $\mathrm{Lu}^{39}$ developed a finite-element method that can be used to resolve the correction parameter observed in the Hertz model. This model uses viscoelastic integrals while ramping load and stress relaxation conditions through finite lateral and vertical dimensions. Additional new models and laws based on Newton, Maxwell, Voigt, Boltzmann, Tsay, Burgers, Weichert, and Kelvin can facilitate the prediction and interpretation of viscoelastic properties of cells for nanoindentation. ${ }^{40,41}$ All models outlined above describe and evaluate AFM forcedisplacement curves, rather than relying on the classical Hertz model that does not allow for larger deformations and nonlinearity. ${ }^{42}$

It is hypothesized that minute changes in cell volume and shape also contribute to important signaling for cell proliferation, death, and migration. Therefore, a new mathematical model developed by Jiang's group ${ }^{43}$ considers cellular volume and pressure by incorporating 
important parameters such as water permeation, mechanosensitive channels, active ion pumps, and active stresses in the cortex. The nanomechanical properties of live cells were first studied using AFM force curves in 1993. ${ }^{38,4}$ Subsequent research successfully implemented this new model to study the differentiation between transformed (cancerous) and nontransformed (normal) cells. ${ }^{45,46}$ In general, all these preliminary data suggest that tumors or cancerous cells are softer as well as highly deformable in terms of their elastic moduli compared to healthier counterparts or cells. ${ }^{25}$ It is also possible to specifically detect glycans on a plasma membrane of cell lines using the AFM indentation method by modifying the AFM tip with three distinct lectins: concanavalin A, lectins from Sambucus nigra, and lectins from Phaseolus vulgaris. ${ }^{47}$

\subsection{Factors that Influence Nanomechanics}

Validation of data obtained by nanoindentation experiments varies and primarily depends on the substrate, instrument condition, and environment used for experiments. Substrates such as glass cover slips, ${ }^{48}$ tissue culture polystyrene, ${ }^{49,} 50$ chlorapatite single crystals, ${ }^{51}$ uncoated or coated with fibronectin/collagen I, ${ }^{52}$ poly(glycerol sebacate) elastomers, ${ }^{53}$ and poly(lactic-co-glycolic acid) (PLGA), ${ }^{54}$ are conventionally used in nanoindentation procedures. Human cells respond via alterations in their mechanics to the synthetic and biological substrate to which they adhere. ${ }^{55}$ In biological applications, the substrate stiffness is always greater than the cells or tissue used for nanoindentation, ${ }^{56}$ except in the case of tissue engineering scaffolds where the two are well matched. In general, variations in stiffness have been observed between cells in the different regions of the substrates. Under ideal conditions, the stiffness order of cells/tissues is as follows: substrate > dispersion > central regions > peripheral regions. In the case of fibroblasts, peripheral regions can be stiffer than the regions above the nucleus. Furthermore, nanoindentation results are greatly influenced by fixation and other processes used for cell measurements. Recent studies support that significant differences arise in cell stiffness due to fixation. Paraformaldehydefixed mouse embryonic fibroblasts (NIH/3T3) and human epithelial cancer cells (SW-13) exhibit at least ten times higher Young's modulus $\left(E>5 \times 10^{4} \mathrm{~Pa}\right)$ over their living counterpart cells $\left(E \sim 5 \times 10^{3} \mathrm{~Pa}\right)$ during steady-state measurements. ${ }^{57}$ Chemical fixation procedures also alter the elasticity, adhesion behavior, and membrane properties of cells. Additionally, substrate coating with artificial materials further interferes with cellular adhesion, thereby influencing AFM indentation results. ${ }^{30}$ Hydrophilic groups such as hydroxyl, polyethylene glycol, carboxyl, amine, and hydrophobic alkyl and phenyl groups are commonly employed coatings. In an elaborate study, positively charged silica microspheres modified by a silane coupling agent of $N$-trimethylsilylpropyl- $N, N, N$ trimethylammonium chloride or $N$-methylaminopropyltrimethoxysilane showed a greater adhesion force with melanoma cells ${ }^{58}$ due to the electrostatic attraction between the positively charged microsphere surface and the cell surface, while the unmodified polystyrene microsphere surface had no significant affinity. It has also been observed that the stiffness of cells is altered by the nature of the substrate that cells are exposed to. 59 


\section{TRANSFORMATION OF NORMAL CELLS TO CANCER CELLS}

Transformation of healthy cells into cancerous cells arises from alterations in the barriers of cell membrane and the internal/external microenvironments. ${ }^{60,61}$ In this process, cellular physiological factors include change in the overall energy conversion process, cell surface alterations and recognition, cellular transport, signal transduction, cell survival, and differentiation of cells. In many cases, significant contributions of mechanical properties of cells are largely governed by their cytoskeleton. The cell cytoskeleton is highly regressed and transforms into an irregular and ompliant state under differentiated, highly mitotic, or cancerous phase. ${ }^{62}$ Additionally, many other internal cellular organelle that are associated with nucleus size, chromatin organization/condensation, and epithelial mesenchymal transition (EMT) are responsible for regulating cellular biomechanical measurements. ${ }^{61}$ Therefore, a significant variation in cellular nanostructures and mechanics can be directly influenced by the cancerous condition of cell. ${ }^{28}$

Transforming growth factor- $\beta$ (TGF- $\beta$ ) acts as a tumor suppressor by inhibiting proliferation and inducing apoptosis in early stages of cancer progression, while also accounting for EMT and cell motility when the disease progresses. The reason for this unusual characteristic was examined on normal murine mammary gland cells and kidney epithelial cells cultured on polyacrylamide gels. The results showed decreasing rigidity increased TGF- $\beta 1$-induced apoptosis. ${ }^{63} \beta$-catenin is a dual function protein, regulating the coordination of cell-cell adhesion and gene transcription. It has been found to play a significant role in tumorigenesis. ${ }^{64,}{ }^{65}$ Single molecule force microscopy of $\beta$-catenin reveals low mechanical stability, and several armadillo repeat region repeats are observed to be unfolded and thus considered chemically active for its ligands. ${ }^{66}$ This study proposed that $\beta$-catenin could serve as a mechanical safeguard under high forces to protect the links between cadherin and the actin cytoskeleton. A recent review indicates that various critical steps are involved in mechanical contributions of cancer cells and tissues to dysplasia, invasion of the extracellular matrix (ECM), and metastasis. ${ }^{67}$

Cross et al. ${ }^{68}$ demonstrated that live lung, breast, and pancreatic metastatic cancer cells obtained from body fluids of patients are apparently distinguished from normal ones by stiffness, although both cell types exhibit very similar morphologies. Another study from this group also confirmed that metastatic cancer cells promote elastic modulus up to $80 \%$ with a narrow distribution compared to normal cells. ${ }^{69}$ This indicates that cancer cells show increased deformability compared to normal cells due to alterations in biochemical processes. Adipose-derived stem cells promote gastric cancer cell growth, migration, and invasion characteristics. ${ }^{70}$ Deriving the mechanical properties from such stem cells will delineate important information. A clear enhancement ( 10-17 times) in Young's moduli between living and dead undifferentiated adipose-derived stem cells was observed by $\mathrm{Hu}$ et al. ${ }^{71}$ Another study demonstrated that an increased compliance of cancerous and precancerous cells may behave in a "crumble and yield" manner. ${ }^{45}$ This study revealed the order of Young's moduli at $1 \mathrm{nN}$ stiffness of indentation force: normal squamous cells (EPC2) $(4.7 \mathrm{kPa}$ live and $9.9 \mathrm{kPa}$ fixed) $>$ metastatic (CP-A) (3.1 kPa live and $2.9 \mathrm{kPa}$ fixed) $>$ dysmoplastic esophageal cells (2.6 kPa live and $2.1 \mathrm{kPa}$ fixed) ${ }^{72}$ 
Nanoindentation of individual cancer or metastatic cell(s) may not describe the in vivo condition of cancerous cells, which are highly connected with stromal cells. To investigate the behavior of such proprietary cancer cells, Wilson et al. ${ }^{73,74}$ implemented a coculture approach consisting of corneal stromal cells, fibroblasts, and type I collagen hydrogels constructs. Under such environment, nanoindentation results suggest that TGF- $\beta 1$ and wortmannin media supplementation significantly affect stromal cell behavior and differentiation. These findings also corroborate cell viability, phenotype, morphology, and protein expression. EMT potentiates the ability of cancer cells to migrate and invade. It is accepted that the majority of cancer mortality is due to metastatic disease. Defining the transition to metastasis by any biological and physical activity provides a foundation essential for improving cancer therapies. In an attempt to delineate pre-EMT to post-EMT advanced dendrimer, a modified tip was used in nanoindentation experiments. ${ }^{75}$ This method enhances force sensitivity in measuring actin dynamics of ovarian cancer SKOV-3 cells upon binding of integrin $a 5 \beta 1$ to fibronectin. Post-EMT SKOV-3 cells induced by TGF- $\beta$ produced a $41 \mathrm{nN}$ adhesive mechanical force compared to $17 \mathrm{nN}$ in pre-EMT SKOV-3 cells. This method provides a direct quantitation of faster migration characteristics of post-EMT cells. Elastic modulus of the enriched cancer stem-like cells/tumor-initiating cell population $(0.32 \pm 0.12 \mathrm{kPa})$ are about $46 \%, 61 \%$, and $72 \%$ softer $(P<0.0001)$ than their aggressive late stage, intermediate, and nonmalignant early-stage murine ovarian surface epithelial counterparts, respectively (Fig. 3) ${ }^{10}$ Similarly, a decrease in elastic modulus was accompanied by epithelial-mesenchymal transition, F-actin, $\beta$-tubulin, nucleus size, and cytoplasm (N/C) ratio in the case of metastasis tongue squamous cell carcinoma cells. ${ }^{76}$ Furthermore, to distinguish additional metastatic prostate cancer cell behavior, PC-3 (derived from bone marrow and $\mathrm{LNCaP}$ ) lymph node derived, was proposed for adhesion nanoindentation experiments in the presence of bone marrow derived mesenchymal stem cells (SCP1 cell line) and collagen I. ${ }^{77}$ The nanoindentation experiments were conducted using a tipless silicon nitride cantilever (with a spring constant of $0.01 \mathrm{~N} / \mathrm{m}$ ) to deposit cancer cells onto a monolayer of SCP1 cells or SCP1 cocultured with collagen I. The binding affinity determined from the force-distance curves was recorded while the piezo traveled in a closed loop up to $20 \beta \mathrm{m}$ at an approach velocity of $7 \beta \mathrm{m} / \mathrm{s}$ until a trigger force of $100 \mathrm{pN}$ and a retraction velocity of $3 \beta \mathrm{m} / \mathrm{s}$ was reached. This study indicates that PC-3 cells demonstrate a greater binding affinity with SCP1 cells and collagen I than LNCaP cells. Yuen et al. ${ }^{78}$ described a difference between normal and abnormal lymph nodes using pig lymph node tissues in agar-gelatin phantoms. This report suggested that there was no significant difference in the effective strain and Young's modulus at peripheral and middle regions of the lymph nodes, but this is distinctly different from observations in normal lymph node. Cumulative nanoindentation data have revealed that the mechanical properties of individual cells is valuable information that can delineate growth, motility, and metastasis phases of cancer cells and tissues. ${ }^{28,79}$ Malignant thyroid cancer cells are either less elastic or less viscous than their normal counterparts, while metastatic cancer cells display significantly lower deformations. It was also observed that elastic moduli of cancer cells are significantly lower than that of normal cells on days 2 and 3 compared to day $1 .{ }^{80}$

Current AFM nanoindentation techniques are highly suitable for measuring elastic properties of whole cells in a firmly adhered stage; however, it is difficult to probe 
nonadherent cells. To overcome this issue, nonadherent cells were immobilized in specially designed micro-fabricated wells and measured at low deformation rate. ${ }^{81}$ In this setup, at a piezo extension rate of p $415 \mathrm{~nm} / \mathrm{s}$, myeloid (HL60) cells $(E=855 \pm 670 \mathrm{~Pa})$ are 18 and 6 times stiffer than lymphoid (Jurkat) $(E=48 \pm 35 \mathrm{~Pa})$ and human neutrophils $(E=156 \pm 87$ $\mathrm{Pa}$ ), respectively. The significant changes arise due to leukocytosis in human leukemia cells. Roberts et al. ${ }^{82}$ have demonstrated that the transformation of mouse ovarian surface epithelial cells from healthy to benign to malignant exhibits significant alterations in cytoskeleton integrity. Their investigation of cell elasticity suggests that latrunculin A (actin-targeting drug) significantly lowers elasticity and viscosity of cells in simple indentation and stress relaxation methods. ${ }^{83}$ However, there was no significant change observed with microtubule affecting drugs such as suberoylanilide hydroxamic acid (SAHA, a histone deacetylase inhibitor) and nacodazole. Another investigation of MDA-MB-231 cells after SAHA treatment did not show a significant change in Young's modulus of cells as determined by the Strobl ${ }^{84}$ test. The peak modulus of the cells was shifted from 0.2 to $0.24 \mathrm{kPa}$ after treatment with SAHA. Interestingly, they also found that SAHA treatment increased circular and star microstructures by $\sim 1.75$ - to 2.5 -fold in cell length and $\sim 1.5$ - to 2.8-fold in cell area due to increased tension within the actin cytoskeletal structure and increased microtubule network extension of the cells.

Adhesion of cells to the ECM is a key property of cells that has an important function in cell physiology. ECM is also responsible for sensing mechanical cues and offers possible engagement and clustering of integrins and formation of focal adhesions via the actin cytoskeleton. A key element in ECM is collagen I, which increases local stiffness up to 50 times. This observation is further confirmed by theoretical simulations and gives a better understanding of the interplay between fiber mechanics and the network organization. ${ }^{85}$ Indentation experiments as well as molecular simulations have been performed on individual collagen filaments. ${ }^{86}$ Keratin filaments are also responsible for mechanical properties of epithelial pancreatic cancer cells (Panc-1). The elastic modulus of living Panc-1 cells ranged from 100 to $500 \mathrm{~Pa}$ while the extracted in situ subcellular keratin intermediate filament network in Panc-1 cells show elastic modulus of only $10 \mathrm{~Pa}$. The reason for this vast difference is due to the fact that keratin network extraction leads to removal of microfilaments, microtubules, membranes, and other soluble cytoplasmic components, which dissolve filamentous fibers and the viscosity from the cytoplasm. Concurrently, Sadeghi et al. ${ }^{87}$ used three different strain energy models, namely, Ogden, Yeoh, and Polynomial, with hyperelastic properties of deflated lung tissue via an inverse finite element approach. The noncytoskeleton (lipid) region may also play a crucial role in determining cancer cell phenotype. Although there was not a significant difference in cytoskeleton and lipid region adhesive forces in MDA-MB-435 cells $(0.291 \pm 0.018 \mathrm{nN}$ for cytoskeleton vs. $0.298 \pm 0.024 \mathrm{nN}$ for lipid), MDA-MB-435-BRMS1 expressed cells (transformed cells) were significantly different in their biophysical and biochemical homogeneity of the membrane surface, reflecting an increased adhesive force at lipid regions $(0.477 \pm 0.030 \mathrm{nN})$ compared to cytoskeleton regions $(0.173 \pm 0.025 \mathrm{nN}) .{ }^{62}$ A study by Baker et al. ${ }^{88}$ offered novel insights on mammary epithelial cell (MEC) transformation into breast cancer. This study was conducted in human-derived MCF10A. MECs overexpressed either ErbB2, 14-3$3 z$, or both ErbB2 and 14-3-3z, with empty vector as a control, which confirms that matrix 
stiffness dictates the intracellular mechanical state of MECs. Integrated models suggest cancer-associated fibroblasts drive the progression of metastasis through cell population, paracrine, and mechanical dynamics. ${ }^{89}$

\section{CANCER TREATMENT AND DIAGNOSIS}

Many current therapeutic agents slow the growth of potential cancer cells in the short term, but their long-term efficacy may be clouded by the cancer's development of de novo (intrinsic) and acquired (extrinsic) resistance to anticancer agents, ${ }^{90}$ which leads to recurrence and relapse of cancer. Therefore, the pharmaceutical industry is now focused on developing drugs that can target multiple pathways instead of drugs that target a single pathway. In a similar context, in addition to utilizing conventional cytotoxicity evaluation methods such as ATP bioluminescence, cell viability or cell proliferation [(3-[4,5dimethylthiazol-2-yl]-2,5 diphenyl tetrazolium bromide, MTT or (3-(4,5-dimethylthiazol-2yl)-5-(3-carboxymethoxyphenyl)-2-(4-sulfophenyl)-2H-tet razolium, inner salt, MTS], clonogenic, methylene blue, migration, or wound healing biological assays, etc., it is important and timely to study nanomechanical properties in order to define targets, design therapeutics, develop drugs, and monitor their efficacy. ${ }^{5}$ Although conventional methods provide substantial basic and cellular information, they fail to reveal microstructural interactions at the interface of the cellular membrane surface and drug molecule(s). A better understanding of the associated problems, such as recurrence and resistance, would enable the designing of experimental conditions to more closely mimic conventional chemotherapy. Therefore, nanoindentation experiments will potentially lead to improvements in drug effectiveness and accurate cytotoxicity estimations.

The frequency of chemotherapy use in oncology has increased extensively, where specific gene proteins or pathways that are disordered during tumorigenesis are targeted. Some of these drugs display greater efficacy than others in eradicating tumors. This signature can be determined by nanoindentation. Chemotherapy (doxorubicin and dexamethasone) induced cell death increased the stiffness of acute lymphoblastic leukemia and acute myeloid leukemia cells that were isolated from the blood of patients with newly diagnosed acute leukemia. ${ }^{91}$ The degree of cell death and associated increase in stiffness of leukemia cells depends on the microfluidic channels, which varies by cell population. The progression of cell death and increase of stiffness is attenuated by disruption of the actin cytoskeleton. In vitro examination of HL60 (myeloid) and Jurkat (lymphoid) cells exposed to daunorubicin and dexamethasone indicated the chemotherapy type dominates the kinetics of cell stiffness, not the leukemia cell type. The work by El Kaffas et al. ${ }^{92}$ also demonstrated that elasticity of MCF-7 breast cancer cells significantly increased upon paclitaxel exposure for $24 \mathrm{hr}$.

Paclitaxel exposure increased the elastic and viscous moduli to $191.3 \mathrm{~Pa}(>8000 \times)$ and $9 \mathrm{~Pa}$ $(\sim 9 \times)$, respectively, in low-frequency shear modulus measurements $\left(1 \mathrm{rad} \mathrm{s}^{-1}\right)$. At higher frequencies $\left(10 \mathrm{rad} \mathrm{s}^{-1}\right)$, these values are reduced to $188.5 \mathrm{~Pa}(\sim 60 \mathrm{x})$ and $1.7 \mathrm{~Pa}(\sim 1.1 \times)$, respectively. Another interesting study correlated the biomechanical composition of the ECM as a critical regulator of cellular behavior. ${ }^{40,93,94}$ The developed in vitro system of "mechanically tunable" matrix-coated polyacrylamide gels promote hepatocellular carcinoma cell proliferation. After treating cells with cisplatin, survived cells proliferated to a significant number of colonies in a stiff microenvironment. This suggests that increased 
matrix stiffness promotes proliferation and leads to resistance. Cytoskeleton-destabilizing agent (Cyt-B) attenuated the average elastic modulus of lymphocyte and Jurkat cells by the disruption of the actin filaments. ${ }^{95}$ Cisplatin-resistant ovarian cancer cells (OVCAR5-CisR and SKOV3-CisR) respond to a combination of cisplatin and Cyt-B treatment by reducing the elastic modulus from $\sim 1.75 \mathrm{kPa}$ to $\sim \leq 7.5 \mathrm{kPa}$ (Fig. 4). ${ }^{96}$ Again, this study suggests chemoresistance is highly associated with extensive actin filaments in cytoplasm to peripheral regions rather than sensitive cells. Another drug, CB1a, showed dose-dependent toxicity toward NCI-H460 lung cancer cells while sparing normal MRC-5 lung cells. ${ }^{97}$ This characteristic was also accompanied by a declining Young's modulus ( $60 \%)$ within $5 \mathrm{~min}$ of CB1a treatment. In contrast, under mechanical forces the growth rate as well as effectiveness of clinically relevant drugs such as cisplatin, paclitaxel, doxorubicin, and KUdrug (experimental drug from the University of Kansas) (Tables I and II) against the A549 cell line increased the effectiveness of zactima against NCI-H358 cell lines. ${ }^{98}$ Introducing such respiratory mechanical forces that mimic physiologically relevant conditions may help to develop anticancer drugs for successful clinical translation.

Natural chemopreventive agents such as curcumin, epigallocatechin gallate (EGCG), and their nanoformulations possess various biological photoelectric activities against cancer cells. ${ }^{99-108}$ For the first time, Watanabe et al. ${ }^{102}$ reported low cell stiffness with low Young's modulus values associated with high cell migration. These findings demonstrate elevated cell stiffness in B16 melanoma cell variants and in (2)-EGCG-treated cells. Another study also delineated the effects of EGCG on patients' metastatic tumor cells and A549 cells through biomechanical response. ${ }^{101}$ These data indicate that EGCG selectively targets human metastatic cancer cells but not normal mesothelial cells. The average Young's modulus of the untreated tumor and normal cells was found to be $0.41 \pm 0.18 \mathrm{kPa}(n=164)$ and $2.53 \pm 1.23 \mathrm{kPa}$, respectively. Treating these cells with EGCG resulted in a significant increase in stiffness of tumor cells to $2.54 \pm 1.27 \mathrm{kPa}(n=154)$ while stiffness of normal cells, $2.48 \pm 1.37 \mathrm{kPa}(n=156)$, did not change significantly. Another study aimed to test the real-time ultrastructural cellular drug interactions as evidenced by imaging and AFM nanoindentation. ${ }^{8}$ In detail, this study demonstrated substantially changed cell membranes and roughness of human cervical (HeLa), human hepatocellular liver (HepG2), and rat glioma (C6) cancer cells upon short-term exposure to colchicine or cytarabine. The results of this study provide a new rationale for the establishment of a real-time visual examination of toxicity. Similarly, immune therapy can also be evaluated by this novel indentation technology. For example, coculture of lymphocytes and K562 cells for $3 \mathrm{hr}$ promoted protrusions on the cell surface and underwent apoptosis or necrosis. This is evidenced by significant alterations in the roughness of cell membrane due to damage and membrane lipid compositions. Another natural product, namely chrysin-organogermanium (IV) complex (Chry-Ge), was examined as an anticancer compound against MCF-7, HepG2, and Colo205 human cancer cell lines. ${ }^{109}$ This compound exhibited enhanced anticancer effects on highly selective tumor cells by disorganized cytoskeletal network and fragmented morphology while sparing normal cells. This arises from reactive oxygen species (ROS)-dependent mitochondrial and apoptosis pathway. The toxicity on MCF-7 cells was also verified by force measurements that indicated a significant decrease in Young's modulus from $1.711 \pm$ $0.864 \mathrm{MPa}$ to $0.0245 \pm 0.010 \mathrm{MPa}$ upon treatment. Similarly, multifaceted effects of 
phytochemicals, such as triterpene saponins and desglucoanagalloside B on human prostate cancer cells (DU-145 and PC-3 cells), were reported. ${ }^{110}$ This study further indicates inhibition of cell motility; CIL-1 (desglucoanagalloside B) attenuates the invasive potential of prostate cancer cells through an effect on their elasticity. Human lung cancer cells respond to phytohemagglutinin erythroagglutinating (PHA-E) (extracted from red kidney beans) by blocking the epidermal growth factor receptor (EGFR). ${ }^{111}$ PHA-E and EGF bind to EGFR with a force of $207.14 \pm 74.42 \mathrm{pN}$ and $183.65 \pm 86.93 \mathrm{pN}$, respectively, indicating that the binding affinity of PHA-E to EGFR was one order higher than EGF to EGFR. ${ }^{111}$ Further, superior anticancer effects of PHA-E over EEGF were confirmed in A-549 cells. Therefore, PHA-E could be a new target molecule for lung cancer treatment.

A prototypical example of the interactions a single molecule with the poorly understood agonist/receptor interaction, that is, leuprorelin acetate's long-lasting effect on gonadotropin-releasing hormone $(\mathrm{GnRH})$ (also known as Luteinizing-hormone-releasing hormone, LHRH) receptors of prostate cancer cells, is highly useful in cancer therapeutics. ${ }^{47}$ Tumor necrosis factor related apoptosis-inducing ligand (TRAIL) is a promising apoptotic agent that is frequently used in cancer research due to its selectivity toward tumor cells. Targosz-Korecka et al. ${ }^{48}$ proposed AFM nanoindentation combined with fluorescence methods to reveal the biomechanical aspects involved in this chemoresistance process. This study demonstrated that an increase in mechanical cell stiffness arises when the inhibition of apoptosis occurs by TRAIL in HEp2 cells. On the other hand, HEp2 cells treated with actinomycin D led to the depolymerization of F-actin and thus a perceived decrease in cell stiffness, which is associated with the Bcl-2 pathway. The stiffness of NIH3T3 cell membrane in response to serum conditions and nocodazole depends on the interplay between dynamically unstable microtubules, stable microtubules, and intermediate filaments, indicating a transient metastability. ${ }^{112}$ Another finding suggests that sphingosine treatment on murine ovarian surface epithelial cells (cancer stem-like/tumor-initiating cells) led to an increase in the elastic moduli by more than $46 \%(0.47 \pm 0.14 \mathrm{kPa}, p<0.0001) .{ }^{10}$ All these results provide evidence that cell environment conditions dictate the most desirable mechanical response.

The adhesion forces vary significantly between the polystyrene microspheres with different size or surface functional groups and the melanoma (B16F10) cells. ${ }^{30}$ It was found that the contact area increases with the increase of sphere diameter. The adhesion force was found to be larger for the carboxyl-modified polystyrene microspheres compared to the unmodified polystyrene microspheres. However, the overall density of carboxyl groups and the zeta potential have no significant influence. The anticancer activity of selenium nanoparticles (Se NPs) in MCF-7 breast cancer cells have been investigated by nanoindentation and changes in cell membrane, CD44 molecule expression, and amounts of F-actin were compared. ${ }^{113}$ Control MCF-7 cells had a Young's modulus of 5.05 $\pm 2.43 \mathrm{MPa}$. When these cells were treated with Se NPs, Young's modulus was only $0.69 \pm 0.31 \mathrm{MPa}$. This observation was consistent with many other drug treatments. An increased interaction of Arg-Gly-Asp peptide (integrin inhibitor) with melanoma cancer cells occurred after modification with carboxyl or hydrophobic-modified polystyrene microspheres. ${ }^{30}$ These results improve the understanding of immunomodulation in a therapeutic setting. 
There are several clinically improved drug-targeted NPs under clinical trials aimed at improving targeting efficacy and lowering side effects, which can potentially be the next generation of therapeutics using nanomedicine. Currently, polymer NPs are the most widely used formulations. Therefore, Vasir and Labhasetwar ${ }^{114}$ examined adhesive interactions of PLGA NPs and cell membranes using a modified AFM tip coated with NPs. The adhesion force quantification was distinctly different between unmodified $(280 \mathrm{pN}$ max and $20 \mathrm{pN}$ min) and modified (1200 pN max and $50 \mathrm{pN}$ min) NPs. The functionalized NPs exhibited a sixfold increase in adhesion events on cell membrane compared to unmodified NPs. This study serves to indicate that this technique can be extended to investigate NP-cell interactions under various biological conditions to uncover the role of nanomedicine in cancer therapeutics. ${ }^{5,115-117}$

\section{CLINICAL VALIDATION}

Nanoindentation techniques can measure the elastic response of cells and tissues, which is a subject of interest in cancer therapeutics and diagnosis. ${ }^{28}$ Nanoindentation can provide timedependent elastic deformation behavior of cells and tissues. The concept of imaging the spatial distribution of tissue elasticity is already used in medical applications. However, developing existing elastic modulus data as a clinical tool requires additional research. It is of great medical benefit to be able to differentiate normal cells from cancer cells and various states of cancer(s) cells by mechanical properties using nanoindentation. Furthermore, an expanded knowledge of elasticity of cancer cells is useful in experiments, drug-target interaction with cancer cells, ligand-receptor interactions, and adhesion force can be used to directly measure the individual near-physiological condition of cancer cells. A study conducted by Samani and Plewes has successfully measured elastic modulus of intact ex vivo breast cancer tissues. ${ }^{118}$ The proposed methodology is robust and accurate. Their preliminary results indicate that a benign lesion and malignant tumors are $\sim 5$ and $\sim 10$ times more rigid than normal breast tissues. An in vitro indentation test system was designed to assess the diagnostic capacity of prostate diseases. ${ }^{119}$ This study investigated viscoelastic properties of human prostate tissues at actuation frequencies between $0.5 \mathrm{and} 30 \mathrm{~Hz}$ for comparison with normal tumor tissues. Validation of nanoindentation stiffness data of ex vivo prostate cancer tissue versus normal cells was further confirmed by the response of a resonance sensor-discriminating radical prostatectomy. ${ }^{120}$ The accuracy of the stiffness curve is 0.941 for a loading force of $12.8 \mathrm{mN}$. Another study correlated robotic 60 nanoindentation data for five prostate specimens in combination with magnetic resonance imaging scans. ${ }^{121}$ A $90 \%$ (54/60) concordance rate was observed between the location mapping from the robotic indentation and imaging scans. The sensitivity and specificity of the robotic indentation system were discovered to be approximately $87.9 \%$ and $92.6 \%$, respectively. More importantly, the indentation technique was able to determine invasiveness and malignant potential of pulmonary lesions when examining 114 groundglass opacities (GGO). ${ }^{122}$ Based on this indentation data, 14 (12\%) and 16 (14\%) of these GGO lesions were categorized as invasive lung cancer and minimally invasive adenocarcinoma, respectively.

Nanoindentation in live and snap-frozen mammary tissues was used to examine the importance of tissue rigidity in cancer cells and contribution of the ECM and vasculatures. ${ }^{70}$ 
This study suggested that isolated transformed MECs were intrinsically stiffer than their normal counterparts. At the same time, the malignant epithelium in situ was far stiffer than isolated breast tumor cells. Additionally, the vascular bed within the tumor core was substantially stiffer than the large patent vessels at the invasive front that are surrounded by the stiffest ECM. A simple analytical observation of nanoindentation confirms $84 \%$ of the variation in the spine bone stiffness and strength of all metastatic prostate, breast, lung, ovarian, or colon cancer cells received from 15 patients (41 specimens) when compared to 96 noncancerous specimens. This measurement can effectively be used as a tool to determine the load capacity of bones altered by metastatic cancer, osteoporosis, or both. ${ }^{123}$ Screening for prostate cancer by serum prostate-specific antigen (PSA) and digital rectal examination (DRE) is widely used. The PSA and DRE approaches predict either high-grade or clinically significant tumors. The nanoindentation technique is able to provide kinesthetic feedback from regions of prostate cancer tissues (ex vivo examination). ${ }^{72}$ The elastic moduli are higher in tissues with a Gleason score of 8 or with a tumor volume $>5 \mathrm{~cm}^{3}$ compared to normal tissues. Another study reported the indentation loading response of a resonance sensor used to discriminate between prostate cancer tissue specimens from ten patients and normal tissue. ${ }^{120}$ A recent finding ${ }^{124}$ confirmed that normal and benign tissues of human breast biopsies exhibit uniform stiffness profiles obtained in a single distinct peak, while malignant tissues have a broad distribution due to tissue heterogeneity (Fig. 5). Similar corelative observations were found in systematic experiments on MMTV-PyMT (mouse mammary tumor virus-polyoma middle $\mathrm{T}$ antigen) transgenic mice, which mimic early to metastatic human disease.

The validation of nanoindentation experiments can further be extended to measurement of the stiffness of leukocytes as compared to the microbead-conjugated cancer cells (circulated tumor cells, CTC). ${ }^{125}$ Combining CTC isolation technology and nanoindentation hybrid platform will result in high recovery rates as well as information on the state of cancers for superior diagnostics. ${ }^{125}$ Another group investigated nanoindentation experiments and drugtarget interactions directly on patient cancer cells, which mimic human in vivo conditions. ${ }^{71}$ The Gaussian fit of the histogram of nanoindentation binding force of CD20-rituximab on B-cell lymphomas was much higher than normal cells. ${ }^{64}$ This protocol was extended to measure CD-20-antibody interaction on the pathological samples derived from the bone marrow of a follicular lymphoma patient. ${ }^{11}, 65$ However, in some cases, nanomechanical analysis of cancer cells and their counterparts reveal similar elasticity, which may not be sufficient to distinguish. ${ }^{126}$ Therefore, analyzing obtained nanomechanical analysis data with other complementary investigative biological studies is necessary for a better understanding of cellular elasticity and cancer. ${ }^{6,12,75}$

\section{CONCLUSIONS AND FUTURE PROSPECTS}

Basic knowledge of bionanomechanical profiles of normal, benign, and malignant biopsies brings together biology and new technologies for improved diagnosis and therapies. Cellular response is manifested in several biochemical expressions as well as through changes in mechanical response to loading. This review summarizes the various elastic modulus data on cells and tissues necessary to establish differences between normal and diseased mammalian cells. The viscoelastic property bridges the gaps between cellular behavior of normal cells 
and cancer phenotype cells. The mission is to understand the response of cancer cells in terms of nanomechanical properties to drug treatments. Such information can potentially help identify selective and ideal drug(s) that can be useful in clinical settings. Studying nanomechanical properties in three-dimensional (3D) cell culture or scaffold cell culture provides ideal clinical relevance. This information is essential to translate drugs for therapeutic application against cancer and to assess their therapeutic value. 3D measurements of the environment will also open up possible undiscovered novel mechanisms, resistance, and synergistic actions of drug molecules. In such circumstances where delivery of drug is an issue, utilizing cutting-edge NPs offers safe and efficient delivery of the "drug or therapeutic agent."

Extrapolating nanoindentation-derived data may be complex when identifying the type of cancer(s) and its progression; however, other fundamental biological characteristics of cancer will enhance the broad spectrum of its utility. A possible drug response in cell culture model will be helpful in screening and simultaneous cellular structural analysis will discover suitable drug candidates. Utilizing an antibody-coated tip is distinctly useful to identify a better technique for targeting of cancer cells and their specificity. This technique is a complex dynamic process and implementation builds on combining various signaling cascades and microenvironments based on new advances in nanomechanic instrumentation and theories. Another concern is while this technique is highly important for the development of potent anticancer drugs, current understanding of its physiological role on cancer-related immune systems remains unknown. However, nanoindentation is a "see, identify and treat" technique among many biophysical tools that provides a safe tool in biomedical research for possible human therapeutic application. Highly reproducible strategies of nanoindentation are required for such therapeutic evaluations.

\section{Acknowledgments}

The authors thank Cathy Christopherson (Sanford Research/USD) for editorial assistance. This work was partially supported by grants from the National Institutes of Health (RO1 CA142736 to S.C.C. and UO1 CA162106A to S.C.C. and M.J.); Department of Defense (PC073887 to S.C.C. and PC073643 M.J.); and the College of Pharmacy 2013 Dean's Seed Grant of the University of Tennessee Health Science Center (to M.J. and M.M.Y.).

\section{Biographies}

Murali M. Yallapu is currently an Assistant Professor in the Department of Pharmaceutical Sciences and Center for Cancer Research, College of Pharmacy, University of Tennessee Health Science Center, Memphis, TN, USA. He received his Ph.D. (2005) from Sri Krishnadevaraya University, India. He is a recipient of the "Late Prof. A. Kameswara Rao's Gold Medal-1999." He gained Postdoctoral Fellow experience from 2005 to 2011 at the Cleveland Clinic (Cleveland, OH, USA), University of Nebraska Medical Center (Omaha, NE, USA), Sanford Research (Sioux Falls, SD, USA), and Gwangju Institute of Science \& Technology (Gwangju, Korea). Dr. Yallapu has been serving as Editorial Member for various nanotechnology journals. He has been an ad-hoc reviewer for many polymer, nanomaterial, and drug-delivery journals. He has published over 80 peer-reviewed articles and reviews in journals, five book chapters, and over 40 conference abstracts. His work was cited over 2700 times, with an H-index of 30 and an i10-index of 53. His current research 
primarily focuses on the development of nanomaterials and nanomechanics for drugdelivery and biomedical applications.

Kalpana S. Katti is a University Distinguished Professor at NDSU in the Department of Civil Engineering. She joined NDSU in 1997 after receiving a Ph.D. from the University of Washington in 1996. Her primary area of research is in tissue engineering and biomimetics. This project involves design of living-nonliving constructs for replacement of human tissue. She also conducts several research projects in the fields of nanocomposites for structural and barrier applications as well as bionanocomposites such as bone and seashells. Her research has won several awards from professional societies such as Microscopy Society of America and Federation of Societies for Coatings Technology, and she has over 145 publications in journals, conference proceedings, and book chapters in the field. She has received the most cited award from the journal Colloids and Interfaces for the years 2004-2007. She is also an NSF CAREER award grantee. At NDSU she is engaged in faculty and administrator search committees, promotion and tenure, teaching, NSF ADVANCE, and several other committees at department, college, and university levels. She received the Peltier award for innovations in teaching in 2007 and the NDSU 52nd Faculty Lectureship in 2011. Nationally, Dr. Katti has served as chair of the Academic Affairs Committee of Materials Research Society, served on the Publications Committee, and is the 2015 volume organizer of Materials Research Society. She is currently chair of the Biomechanics Committee of American Society of Civil Engineers Engineering Mechanics Institutes and also Vice Chair of the Properties of Materials Committee. She has given over 40 invited lectures at national and international conferences and institutions around the world.

Dinesh Katti is a Professor of the Civil and Environmental Engineering Department at North Dakota State University in Fargo, ND. Dr. Katti's area of expertise is in multiscale modeling of nanoscale materials. His group has made important contributions through discoveries and revelations of key mechanisms that describe the critical role of molecular scale interactions and nano/microstructure on macroscale properties of nanoscale materials. His group works on a variety of nanoscale materials of diverse origins that include geologic (clays and oil shale), synthetic (polymer clay nanocomposites), and biological (bone and seashells) origins. He is an author of three books, seven book chapters, and approximately 150 papers. He has received the John Booker Excellence Award for contributions to geomechanics from IACMAG and the Fred Waldron Award for Excellence in Research. He serves as an associate editor of two journals, Journal of Engineering Mechanics and Journal of Nanomechanics and Micromechanics. He has served as chair of several national committees that include ASCE Properties of Materials Committee, Poromechanics Committee, and Molecular Scale Modeling and Experimentation Committee. He has been invited to give plenary and keynote talks around the world. He is a licensed professional engineer in the state of Washington and has worked on about 125 consulting projects that include projects for Boeing and Microsoft. Dr. Katti received his Doctoral degree in Civil Engineering and Engineering Mechanics from the University of Arizona, Master's degree in Civil Engineering from Indian Institute of Technology, Bombay, and Bachelor's degree in Civil Engineering from National Institute of Technology, Srinagar. He currently serves as Interim Chair of the Civil and Environmental Engineering Department. He has previously 
served as Chair of the Civil Engineering Department and Associate Dean of Research for the College of Engineering at NDSU.

Sanjay Mishra received his Ph.D. in Physics from the University of Missouri-Rolla (MSTU) in 1996. He pursued his postdoctoral studies at the Advanced Light Source-LBNL, Berkeley, CA. He joined the University of Memphis as an Associate Professor of Physics in 1999. Being a materials scientist, his field of interest and expertise spans the area of magnetic nanomaterials, biomaterials, and composite materials. He has published over 95 peer-reviewed journal articles. Currently, his research work is focused on developing "smart" biomaterials for infection and cancer treatment, nanomaterial biointeraction, and novel magnetic nanomaterials.

Sheema Khan is currently a Postdoctoral Fellow at the University of Tennessee Health Science Center. Sheema obtained her Ph.D. at the Indian Institute of Integrative Medicine, India. She worked on the development of anticancer therapeutics from natural products, in particular identifying immune modifiers and targeting critical tumor promoting pathways. During her postdoctoral fellowship in Dr. Chauhan's lab, she has been working on early diagnosis, biophysical evaluation, and therapeutic interventions for cancer(s). Her research studies particularly involve the tumor stromal interactions, mucin biology, and microRNAs. Her work has been published in 11 peer-reviewed journals.

Subhash C. Chauhan recently joined the College of Pharmacy, UTHSC, as Professor. Before joining UTHSC, Dr. Subhash C. Chauhan served as Scientist at the Cancer Biology Research Center, Sanford Research/USD, Sioux Falls, SD. He was also holding an appointment as Associate Professor, Sanford School of Medicine, The University of South Dakota, Sioux Falls, SD. He received his Ph.D. degree from Central Drug Research Institute, India in 1997 and then completed postdoctoral training at Medical College of Ohio (MCO), Toledo, Ohio and University of Nebraska Medical Center (UNMC), Omaha, Nebraska. His primary research interest is to identify and characterize the diagnostic and therapeutic targets for cancer. This research is aimed at identification and characterization of biomarkers that aberrantly express or localize in cancer cells to develop newer tools for early cancer diagnosis. The other interest of his laboratory is to develop a targeted nanotherapy for cancer treatment since nonspecific distribution and suboptimal delivery of the anticancer drug(s) to the tumor cells are the major hindrances in the successful use of traditional chemotherapy. Dr. Chauhan has substantial experience and track record in pancreatic, prostate, cervical, and ovarian cancer, and cancer health disparity areas. He is an author of over 70 research/review articles and book chapters. Recently, the Department of Defense (CDMRP) selected his research work on prostate cancer therapy for research highlight. Currently, he has two RO1/U01 grants funded through NIH/NCI. Additionally, he has successfully secured funding from local, state, federal agencies (NIH and DOD) and a pharmaceutical company (Merck).

Meena Jaggi recently joined the College of Pharmacy, UTHSC, as Associate Professor. Dr. Jaggi has served as an Associate Scientist at the Cancer Biology Research Center, Sanford Research/USD, Sioux Falls, SD. She was also holding an appointment as Associate 
Professor, Sanford School of Medicine, The University of South Dakota, Sioux Falls, SD. She received her Ph.D. degree from Central Drug Research Institute, India in 1998 and then completed postdoctoral training at the University Toledo, Toledo, Ohio and University of Nebraska Medical Center (UNMC), Omaha, Nebraska. She has published over 50 peerreviewed articles and book chapters. Her primary research interest is cancer cell signaling and identification of novel diagnostic and therapeutic targets for cancer treatment. The other interest of her laboratory is to develop nanoparticle-mediated drug and gene therapy for cancer treatment. She is Co-I/Co-PI of two NIH funded (RO1/U01) grants. She has been successful in obtaining funding from local, state, and federal (DOD/NIH) agencies, and a pharmaceutical company (Merck).

\section{References}

1. http://www.wcrf.org/cancer_statistics/world_cancer_statistics.php.

2. Siegel R, Naishadham D, Jemal A. Cancer statistics, 2013. CA Cancer J Clin. 2013; 63(1):11-30. [PubMed: 23335087]

3. Lekka M, Laidler P, Gil D, Lekki J, Stachura Z, Hrynkiewicz AZ. Elasticity of normal and cancerous human bladder cells studied by scanning force microscopy. Eur Biophys J. 1999; 28(4): 312-316. [PubMed: 10394623]

4. Guck J, Schinkinger S, Lincoln B, Wottawah F, Ebert S, Romeyke M, Lenz D, Erickson H, Ananthakrishnan R, Mitchell D, Käs J, Ulvick S, Bilby C. Optical deformability as an inherent cell marker for testing malignant transformation and metastatic competence. Biophys J. 2005; 88(5): 3689-3698. [PubMed: 15722433]

5. Lal R, Arnsdorf MF. Multidimensional atomic force microscopy for drug discovery: A versatile tool for defining targets, designing therapeutics and monitoring their efficacy. Life Sci. 2010; 86(1516):545-562. [PubMed: 20359578]

6. Muller DJ, Dufrene YF. Atomic force microscopy: A nanoscopic window on the cell surface. Trends Cell Biol. 2011; 21(8):461-469. [PubMed: 21664134]

7. Schuh CA. Nanoindentation studies of materials. Mater Today. 2006; 9(5):32-40.

8. Wang J, Wan Z, Liu W, Li L, Ren L, Wang X, Sun P, Zhao H, Tu Q, Zhang Z, Song N, Zhang L. Atomic force microscope study of tumor cell membranes following treatment with anti-cancer drugs. Biosens Bioelectron. 2009; 25(4):721-727. [PubMed: 19734031]

9. Pillet F, Chopinet L, Formosa C, Dague E. Atomic force microscopy and pharmacology: From microbiology to cancerology. Biochim Biophys Acta. 2014; 1840(3):1028-1050. [PubMed: 24291690]

10. Babahosseini H, Ketene AN, Schmelz EM, Roberts PC, Agah M. Biomechanical profile of cancer stem-like/tumor initiating cells derived from a progressive ovarian cancer model. Nanomedicine. 2014; 10(5):1013-1019. [PubMed: 24407147]

11. Yang R, Xi N, Fung CK, Seiffert-Sinha K, Lai KW, Sinha AA. The emergence of AFM applications to cell biology: How new technologies are facilitating investigation of human cells in health and disease at the nanoscale. J Nanosci Lett. 2011; 1(2):87-101. [PubMed: 24416719]

12. Edwardson JM, Henderson RM. Atomic force microscopy and drug discovery. Drug Discov Today. 2004; 9(2):64-71. [PubMed: 15012930]

13. Kuznetsova TG, Starodubtseva MN, Yegorenkov NI, Chizhik SA, Zhdanov RI. Atomic force microscopy probing of cell elasticity. Micron. 2007; 38(8):824-833. [PubMed: 17709250]

14. Chen PY, Lin AY, Lin YS, Seki Y, Stokes AG, Peyras J, Olevsky EA, Meyers MA, McKittrick J. Structure and mechanical properties of selected biological materials. J Mech Behav Biomed Mater. 2008; 1(3):208-226. [PubMed: 19627786]

15. Chen PY, McKittrick J, Meyers MA. Biological materials: Functional adaptations and bioinspired designs. Prog Mater Sci. 2012; 57(8):1492-1704. 
16. Su HN, Chen ZH, Song XY, Chen XL, Shi M, Zhou BC, Zhao X, Zhang YZ. Antimicrobial peptide trichokonin VI-induced alterations in the morphological and nanomechanical properties of Bacillus subtilis. PLoS One. 2012; 7(9):e45818. [PubMed: 23049870]

17. Zeiger AS, Loe FC, Li R, Raghunath M, Van Vliet KJ. Macromolecular crowding directs extracellular matrix organization and mesenchymal stem cell behavior. PLoS One. 2012; 7(5):e37904. [PubMed: 22649562]

18. Jerusalem A, Dao M. Continuum modeling of a neuronal cell under blast loading. Acta Biomater. 2012; 8(9):3360-3371. [PubMed: 22562014]

19. Donnelly E. Methods for assessing bone quality: A review. Clin Orthop Relat Res. 2011; 469(8): 2128-2138. [PubMed: 21116752]

20. El-Safty S, Akhtar R, Silikas N, Watts DC. Nanomechanical properties of dental resin-composites. Dent Mater. 2012; 28(12):1292-1300. [PubMed: 23031485]

21. Pathak S, Swadener JG, Kalidindi SR, Courtland HW, Jepsen KJ, Goldman HM. Measuring the dynamic mechanical response of hydrated mouse bone by nanoindentation. J Mech Behav Biomed Mater. 2011; 4(1):34-43. [PubMed: 21094478]

22. Ho SP, Balooch M, Goodis HE, Marshall GW, Marshall SJ. Ultrastructure and nanomechanical properties of cementum dentin junction. J Biomed Mater Res A. 2004; 68A(2):343-351. [PubMed: 14704976]

23. Katti KS, Mohanty B, Katti DR. Nanomechanical properties of nacre. J Mater Res. 2006; 21(5): 1237-1242.

24. Mohanty B, Katti KS, Katti DR, Verma D. Dynamic nanomechanical response of nacre. J Mater Res. 2006; 21(8):2045-2051.

25. Suresh S. Biomechanics and biophysics of cancer cells. Acta Biomater. 2007; 3(4):413-438. [PubMed: 17540628]

26. Chen J. Nanobiomechanics of living cells: A review. Interface Focus. 2014; 4(2):20130055. [PubMed: 24748952]

27. Pharr GM, Oliver WC. Nanoindentation of silver-relations between hardness and dislocationstructure. J Mater Res. 1989; 4(1):94-101.

28. Lekka M, Pogoda K, Gostek J, Klymenko O, Prauzner-Bechcicki S, Wiltowska-Zuber J, Jaczewska J, Lekki J, Stachura Z. Cancer cell recognition-mechanical phenotype. Micron. 2012; 43(12):1259-1266. [PubMed: 22436422]

29. Oyen M, Taylor D. Special issue on nanoindentation of biological materials. J Mech Behav Biomed Mater. 2009; 2(4):311. [PubMed: 19627836]

30. Shinto H, Aso Y, Fukasawa T, Higashitani K. Adhesion of melanoma cells to the surfaces of microspheres studied by atomic force microscopy. Colloids Surf B Biointerfaces. 2012; 91:114121. [PubMed: 22119216]

31. Heinrich C, Waas AM, Wineman AS. Determination of material properties using nanoindentation and multiple indenter tips. Inter J Solids Struct. 2009; 46(2):364-376.

32. Haydon P, Lartius R, Parpura V, Marchese-Ragona S. Membrane deformation of living glial cells using atomic force microscopy. J Microsc. 1996; 182:114-120. [PubMed: 8683560]

33. Kirmizis D, Logothetidis S. Atomic force microscopy probing in the measurement of cell mechanics. Int J Nanomed. 2010; 5:137-145.

34. Tan JC, Furman JD, Cheetham AK. Relating mechanical properties and chemical bonding in an inorganic-organic framework material: A single-crystal nanoindentation study. J Am Chem Soc. 2009; 131(40):14252-14254. [PubMed: 19757791]

35. Lewis G, Nyman JS. The use of nanoindentation for characterizing the properties of mineralized hard tissues: state-of-the art review. J Biomed Mater Res B. 2008; 87(1):286-301.

36. Putman CA, van der Werf KO, de Grooth BG, van Hulst NF, Greve J. Viscoelasticity of living cells allows high resolution imaging by tapping mode atomic force microscopy. Biophys J. 1994; 67(4):1749-1753. [PubMed: 7819507]

37. Radmacher M, Fritz M, Kacher CM, Cleveland JP, Hansma PK. Measuring the viscoelastic properties of human platelets with the atomic force microscope. Biophys J. 1996; 70(1):556-567. [PubMed: 8770233] 
38. Radmacher M, Tillmann RW, Gaub HE. Imaging viscoelasticity by force modulation with the atomic force microscope. Biophys J. 1993; 64(3):735-742. [PubMed: 19431876]

39. Chen J, Lu G. Finite element modelling of nanoindentation based methods for mechanical properties of cells. J Biomech. 2012; 45(16):2810-2816. [PubMed: 23017378]

40. Sunbuloglu E, Bozdag E, Toprak T, Islak C. Experimental parameter estimation method for nonlinear viscoelastic composite material models: An application on arterial tissue. Comp Meth Biomech Biomed Eng. 2013; 16(12):1249-1261.

41. Chen D-L, Yang P-Y, Lai Y-S. A review of three-dimensional viscoelastic models with an application to viscoelasticity characterization using nanoindentation. Microelectr Reliab. 2012; 52(3):541-558.

42. Murphy MF, Lilley F, Lalor MJ, Crosby SR, Madden G, Johnston G, Burton DR. Evaluation of a nonlinear Hertzian-based model reveals prostate cancer cells respond differently to force than normal prostate cells. Microsc Res Tech. 2013; 76(1):36-41. [PubMed: 23070866]

43. Jin Tong, JS.; Zhou, Jiang. Nanoindentation of biomaterials handbook of nanophysics. Boca Raton, FL: CRC Press; 2010. p. 1-16.

44. Weisenhorn AL, Khorsandi M, Kasas S, Gotzos V, Butt H. Deformation and height anomaly of soft surfaces studied with an AFM. Nanotechnology. 1993; 4:106-113.

45. Fuhrmann A, Staunton JR, Nandakumar V, Banyai N, Davies PC, Ros R. AFM stiffness nanotomography of normal, metaplastic and dysplastic human esophageal cells. Phys Biol. 2011; 8(1):015007. [PubMed: 21301067]

46. Lee MH, Wu PH, Staunton JR, Ros R, Longmore GD, Wirtz D. Mismatch in mechanical and adhesive properties induces pulsating cancer cell migration in epithelial monolayer. Biophys $\mathrm{J}$. 2012; 102(12):2731-2741. [PubMed: 22735523]

47. Lekka M, Laidler P, Labedz M, Kulik AJ, Lekki J, Zajac W, Stachura Z. Specific detection of glycans on a plasma membrane of living cells with atomic force microscopy. Chem Biol. 2006; 13(5):505-512. [PubMed: 16720271]

48. Targosz-Korecka M, Biedron R, Szczygiel AM, Brzezinka G, Szczerbinski J, Zuk A. Stiffness changes of tumor HEp2 cells correlates with the inhibition and release of TRAIL-induced apoptosis pathways. J Mol Recognition. 2012; 25(5):299-308.

49. Khanna R, Katti KS, Katti DR. Experiments in nanomechanical properties of live osteoblast cells and cell-biomaterial interface. J Nanotechnol Eng Med. 2012; 2(4):041005, 041013.

50. Khanna R, Katti DR, Katti KS. AFM and nanoindentation studies of bone nodules on chitosanpolygalacturonic acid-hydroxyapatite nanocomposites. Comp Mod Eng Sci. 2012; 87(6):530-555.

51. Garcia-Tunon E, Couceiro R, Franco J, Saiz E, Guitian F. Synthesis and characterisation of large chlorapatite single-crystals with controlled morphology and surface roughness. J Mater Sci Mater Med. 2012; 23(10):2471-2482. [PubMed: 22806077]

52. Docheva D, Padula D, Schieker M, Clausen-Schaumann H. Effect of collagen I and fibronectin on the adhesion, elasticity and cytoskeletal organization of prostate cancer cells. Biochem Biophys Res Commun. 2010; 402(2):361-366. [PubMed: 20946884]

53. Kossivas F, Angeli S, Kafouris D, Patrickios CS, Tzagarakis V, Constantinides C. MRI-based morphological modeling, synthesis and characterization of cardiac tissue-mimicking materials. Biomed Mater. 2012; 7(3):035006. [PubMed: 22406555]

54. Wang Y, Zhang L, Sun L, Webster TJ. Increased healthy osteoblast to osteosarcoma density ratios on specific PLGA nanopatterns. Int J Nanomed. 2013; 8:159-166.

55. Khanna R, Katti DR, Katti KS. Experiments in nanomechanical properties of live osteoblast cells and cell-biomaterial interface. J Nanotech Eng Med. 2012; 2:13.

56. Horimizu M, Kawase T, Tanaka T, Okuda K, Nagata M, Burns DM, Yoshie H. Biomechanical evaluation by AFM of cultured human cell-multilayered periosteal sheets. Micron. 2013; 48:1-10. [PubMed: 23490209]

57. Codan B, Martinelli V, Mestroni L, Sbaizero O. Atomic force microscopy of 3T3 and SW-13 cell lines: An investigation of cell elasticity changes due to fixation. Mater Sci Eng C. 2013; 33(6): 3303-3308. 
58. McNamee CE, Pyo N, Higashitani K. Atomic force microscopy study of the specific adhesion between a colloid particle and a living melanoma cell: Effect of the charge and the hydrophobicity of the particle surface. Biophys J. 2006; 91(5):1960-1969. [PubMed: 16731555]

59. Guo Q, Xia Y, Sandig M, Yang J. Characterization of cell elasticity correlated with cell morphology by atomic force microscope. J Biomech. 2012; 45(2):304-309. [PubMed: 22115064]

60. Kim Y, Stolarska MA, Othmer HG. The role of the microenvironment in tumor growth and invasion. Prog Biophys Mol Biol. 2011; 106(2):353-379. [PubMed: 21736894]

61. Ingber DE. Can cancer be reversed by engineering the tumor microenvironment? Semin Cancer Biol. 2008; 18(5):356-364. [PubMed: 18472275]

62. Wu Y, McEwen GD, Harihar S, Baker SM, DeWald DB, Zhou A. BRMS1 expression alters the ultrastructural, biomechanical and biochemical properties of MDA-MB-435 human breast carcinoma cells: An AFM and Raman microspectroscopy study. Cancer Lett. 2010; 293(1):82-91. [PubMed: 20083343]

63. Leight JL, Wozniak MA, Chen S, Lynch ML, Chen CS. Matrix rigidity regulates a switch between TGF-beta1-induced apoptosis and epithelial-mesenchymal transition. Mol Biol Cell. 2012; 23(5): 781-791. [PubMed: 22238361]

64. Li M, Liu L, Xi N, Wang Y, Dong Z, Tabata O, Xiao X, Zhang W. Imaging and measuring the rituximab-induced changes of mechanical properties in B-lymphoma cells using atomic force microscopy. Biochem Biophys Res Commun. 2011; 404(2):689-694. [PubMed: 21156157]

65. Li M, Xiao X, Liu L, Xi N, Wang Y, Dong Z, Zhang W. Atomic force microscopy study of the antigen-antibody binding force on patient cancer cells based on ROR1 fluorescence recognition. J Mol Recognit. 2013; 26(9):432-438. [PubMed: 23836471]

66. Valbuena A, Vera AM, Oroz J, Menendez M, Carrion-Vazquez M. Mechanical properties of betacatenin revealed by single-molecule experiments. Biophys J. 2012; 103(8):1744-1752. [PubMed: 23083718]

67. Kumar S, Weaver VM. Mechanics, malignancy, and metastasis: The force journey of a tumor cell. Cancer Metastasis Rev. 2009; 28(1-2):113-127. [PubMed: 19153673]

68. Cross SE, Jin YS, Rao J, Gimzewski JK. Nanomechanical analysis of cells from cancer patients. Nature Nanotech. 2007; 2(12):780-783.

69. Cross SE, Jin YS, Tondre J, Wong R, Rao J, Gimzewski JK. AFM-based analysis of human metastatic cancer cells. Nanotechnology. 2008; 19(38):384003. [PubMed: 21832563]

70. Iwao K, Matoba R, Ueno N, Ando A, Miyoshi Y, Matsubara K, Noguchi S, Kato K. Molecular classification of primary breast tumors possessing distinct prognostic properties. Hum Mol Genet. 2002; 11(2):199-206. [PubMed: 11809729]

71. Hu K, Zhao F, Wang Q. Mechanical characterization of living and dead undifferentiated human adipose-derived stem cells by using atomic force microscopy. Proc Inst Mech Eng H. 2013; 227:1319-1323. [PubMed: 24044923]

72. Ahn BM, Kim J, Ian L, Rha KH, Kim HJ. Mechanical property characterization of prostate cancer using a minimally motorized indenter in an ex vivo indentation experiment. Urology. 2010; 76(4): 1007-1011. [PubMed: 20451976]

73. Wilson SL, Guilbert M, Sule-Suso J, Torbet J, Jeannesson P, Sockalingum GD, Yang Y. A microscopic and macroscopic study of aging collagen on its molecular structure, mechanical properties, and cellular response. FASEB J. 2014; 28(1):14-25. [PubMed: 24025727]

74. Wilson SL, Yang Y, El Haj AJ. Corneal stromal cell plasticity: In vitro regulation of cell phenotype through cell-cell interactions in a three-dimensional model. Tissue Eng Part A. 2014; 20(1-2):225-238. [PubMed: 23895175]

75. Wang Y, Insana MF. Viscoelastic properties of rodent mammary tumors using ultrasonic shearwave imaging. Ultrason Imaging. 2013; 35(2):126-145. [PubMed: 23493612]

76. Zhou Z, Zheng C, Li S, Zhou X, Liu Z, He Q, Zhang N, Ngan A, Tang B, Wang A. AFM nanoindentation detection of the elastic modulus of tongue squamous carcinoma cells with different metastatic potentials. Nanomedicine. 2013; 9:864-874. [PubMed: 23579203]

77. Sariisik E, Docheva D, Padula D, Popov C, Opfer J, Schieker M, Clausen-Schaumann H, Benoit M. Probing the interaction forces of prostate cancer cells with collagen I and bone marrow derived stem cells on the single cell level. PLoS One. 2013; 8(3):e57706. [PubMed: 23472100] 
78. Wing-Han Yuen Q, Zheng YP, Huang YP, He JF, Chung-Wai Cheung J, Ying M. In-vitro strain and modulus measurements in porcine cervical lymph nodes. Open Biomed Eng J. 2011; 5:39-46. [PubMed: 21643424]

79. Lekka M, Gil D, Pogoda K, Dulinska-Litewka J, Jach R, Gostek J, Klymenko O, PrauznerBechcicki S, Stachura Z, Wiltowska-Zuber J, Okon K, Laidler P. Cancer cell detection in tissue sections using AFM. Arch Bioch Biophys. 2012; 518(2):151-156.

80. Prabhune M, Belge G, Dotzauer A, Bullerdiek J, Radmacher M. Comparison of mechanical properties of normal and malignant thyroid cells. Micron. 2012; 43(12):1267-1272. [PubMed: 22522060]

81. Rosenbluth MJ, Lam WA, Fletcher DA. Force microscopy of nonadherent cells: A comparison of leukemia cell deformability. Biophys J. 2006; 90(8):2994-3003. [PubMed: 16443660]

82. Roberts PC, Mottillo EP, Baxa AC, Heng HH, Doyon-Reale N, Gregoire L, Lancaster WD, Rabah R, Schmelz EM. Sequential molecular and cellular events during neoplastic progression: A mouse syngeneic ovarian cancer model. Neoplasia. 2005; 7(10):944-956. [PubMed: 16242077]

83. Ketene AN, Roberts PC, Shea AA, Schmelz EM, Agah M. Actin filaments play a primary role for structural integrity and viscoelastic response in cells. Integr Biol. 2012; 4(5):540-549.

84. Strobl JS, Nikkhah M, Agah M. Actions of the anti-cancer drug suberoylanilide hydroxamic acid (SAHA) on human breast cancer cytoarchitecture in silicon microstructures. Biomaterials. 2010; 31(27):7043-7050. [PubMed: 20579727]

85. Beenakker JW, Ashcroft BA, Lindeman JH, Oosterkamp TH. Mechanical properties of the extracellular matrix of the aorta studied by enzymatic treatments. Biophys J. 2012; 102(8):1731-1737. [PubMed: 22768928]

86. Pradhan SM, Katti KS, Katti DR. Structural hierarchy controls deformation behavior of collagen. Biomacromolecules. 2012; 13(8):2562-2569. [PubMed: 22808993]

87. Sadeghi Naini A, Patel RV, Samani A. Measurement of lung hyperelastic properties using inverse finite element approach. IEEE Trans Biomed Eng. 2011; 58(10):2852-2859. [PubMed: 21724500]

88. Baker EL, Lu J, Yu D, Bonnecaze RT, Zaman MH. Cancer cell stiffness: Integrated roles of threedimensional matrix stiffness and transforming potential. Biophys J. 2010; 99(7):2048-2057. [PubMed: 20923638]

89. Karagiannis GS, Poutahidis T, Erdman SE, Kirsch R, Riddell RH, Diamandis EP. Cancerassociated fibroblasts drive the progression of metastasis through both paracrine and mechanical pressure on cancer tissue. Mol Cancer Res. 2012; 10(11):1403-1418. [PubMed: 23024188]

90. Rauch C. On the relationship between drug's size, cell membrane mechanical properties and high levels of multi drug resistance: A comparison to published data. Eur Biophys J. 2009; 38(4):537546. [PubMed: 19066880]

91. Lam WA, Rosenbluth MJ, Fletcher DA. Chemotherapy exposure increases leukemia cell stiffness. Blood. 2007; 109(8):3505-3508. [PubMed: 17179225]

92. El Kaffas A, Bekah D, Rui M, Kumaradas JC, Kolios MC. Investigating longitudinal changes in the mechanical properties of MCF-7 cells exposed to paclitaxol using particle tracking microrheology. Phys Med Biol. 2013; 58(4):923-936. [PubMed: 23340402]

93. Zhang D, Kilian KA. The effect of mesenchymal stem cell shape on the maintenance of multipotency. Biomaterials. 2013; 34(16):3962-3969. [PubMed: 23473964]

94. Lee J, Abdeen AA, Zhang D, Kilian KA. Directing stem cell fate on hydrogel substrates by controlling cell geometry, matrix mechanics and adhesion ligand composition. Biomaterials. 2013; 34(33):8140-8148. [PubMed: 23932245]

95. Cai X, Xing X, Cai J, Chen Q, Wu S, Huang F. Connection between biomechanics and cytoskeleton structure of lymphocyte and Jurkat cells: An AFM study. Micron. 2010; 41(3):257262. [PubMed: 20060729]

96. Sharma S, Santiskulvong C, Bentolila LA, Rao J, Dorigo O, Gimzewski JK. Correlative nanomechanical profiling with super-resolution F-actin imaging reveals novel insights into mechanisms of cisplatin resistance in ovarian cancer cells. Nanomedicine. 2012; 8(5):757-766. [PubMed: 22024198] 
97. Kao FS, Pan YR, Hsu RQ, Chen HM. Efficacy verification and microscopic observations of an anticancer peptide, CB1a, on single lung cancer cell. Biochim Biophys Acta. 2012; 1818(12): 2927-2935. [PubMed: 22846508]

98. Hendricks P, Diaz FJ, Schmitt S, Sitta Sittampalam G, Nirmalanandhan VS. Effects of respiratory mechanical forces on the pharmacological response of lung cancer cells to chemotherapeutic agents. Fundam Clin Pharm. 2012; 26(5):632-643.

99. Saab MB, Bec N, Martin M, Estephan E, Cuisinier F, Larroque C, Gergely C. Differential effect of curcumin on the nanomechanics of normal and cancerous Mammalian epithelial cells. Cell Biochem Biophys. 2013; 65(3):399-411. [PubMed: 23097022]

100. Saab MB, Estephan E, Bec N, Larroque M, Aulombard R, Cloitre T, Gergely C. Multimicroscopic study of curcumin effect on fixed nonmalignant and cancerous mammalian epithelial cells. J Biophotonics. 2011; 4(7-8):533-543. [PubMed: 21394918]

101. Cross SE, Jin YS, Lu QY, Rao J, Gimzewski JK. Green tea extract selectively targets nanomechanics of live metastatic cancer cells. Nanotechnology. 2011; 22(21):215101. [PubMed: 21451222]

102. Watanabe T, Kuramochi H, Takahashi A, Imai K, Katsuta N, Nakayama T, Fujiki H, Suganuma M. Higher cell stiffness indicating lower metastatic potential in B16 melanoma cell variants and in (-)-epigallocatechin gallate-treated cells. J Cancer Res Clin Oncol. 2012; 138:859-866.

103. Yallapu MM, Dobberpuhl MR, Maher DM, Jaggi M, Chauhan SC. Design of curcumin loaded cellulose nanoparticles for prostate cancer. Curr Drug Metab. 2012; 13(1):120-128. [PubMed: 21892919]

104. Yallapu MM, Ebeling MC, Chauhan N, Jaggi M, Chauhan SC. Interaction of curcumin nanoformulations with human plasma proteins and erythrocytes. Int J Nanomed. 2011; 6:27792790.

105. Yallapu MM, Ebeling MC, Khan S, Sundram V, Chauhan N, Gupta BK, Puumala SE, Jaggi M, Chauhan SC. Novel curcumin-loaded magnetic nanoparticles for pancreatic cancer treatment. Mol Cancer Ther. 2013; 12(8):1471-1480. [PubMed: 23704793]

106. Yallapu MM, Gupta BK, Jaggi M, Chauhan SC. Fabrication of curcumin encapsulated PLGA nanoparticles for improved therapeutic effects in metastatic cancer cells. J Colloid Interface Sci. 2010; 351(1):19-29. [PubMed: 20627257]

107. Yallapu MM, Jaggi M, Chauhan SC. Curcumin nanomedicine: A road to cancer therapeutics. Curr Pharm Des. 2013; 19(11):1994-2010. [PubMed: 23116309]

108. Yallapu MM, Maher DM, Sundram V, Bell MC, Jaggi M, Chauhan SC. Curcumin induces chemo/radio-sensitization in ovarian cancer cells and curcumin nanoparticles inhibit ovarian cancer cell growth. J Ovarian Res. 2010; 3:11. [PubMed: 20429876]

109. Yang F, Jin H, Pi J, Jiang JH, Liu L, Bai HH, Yang PH, Cai JY. Anti-tumor activity evaluation of novel chrysin-organogermanium(IV) complex in MCF-7 cells. Bioorg Med Chem Lett. 2013; 23(20):5544-5551. [PubMed: 24007917]

110. Koczurkiewicz P, Podolak I, Skrzeczynska-Moncznik J, Sarna M, Wojcik KA, Ryszawy D, Galanty A, Lasota S, Madeja Z, Czyz J, Michalik M. Triterpene saponosides from Lysimachia ciliata differentially attenuate invasive potential of prostate cancer cells. Chem Biol Interact. 2013; 206(1):6-17. [PubMed: 23954719]

111. Kuo WT, Dong GC, Yao CH, Huang JY, Lin FH. Evaluation of adhesion force and binding affinity of phytohemagglutinin erythroagglutinating to EGF receptor on human lung cancer cells. Curr Med Chem. 2013; 20(19):2476-2485. [PubMed: 23394551]

112. Pelling AE, Dawson DW, Carreon DM, Christiansen JJ, Shen RR, Teitell MA, Gimzewski JK. Distinct contributions of microtubule subtypes to cell membrane shape and stability. Nanomedicine. 2007; 3(1):43-52. [PubMed: 17379168]

113. Pi J, Yang F, Jin H, Huang X, Liu R, Yang P, Cai J. Selenium nanoparticles induced membrane bio-mechanical property changes in MCF-7 cells by disturbing membrane molecules and F-actin. Bioorg Med Chem Lett. 2013; 23(23):6296-6303. [PubMed: 24140445]

114. Vasir JK, Labhasetwar V. Quantification of the force of nanoparticle-cell membrane interactions and its influence on intracellular trafficking of nanoparticles. Biomaterials. 2008; 29(31):42444252. [PubMed: 18692238] 
115. Turkcan S, Richly MU, Bouzigues CI, Allain JM, Alexandrou A. Receptor displacement in the cell membrane by hydrodynamic force amplification through nanoparticles. Biophys J. 2013; 105(1):116-126. [PubMed: 23823230]

116. Chaudhuri A, Battaglia G, Golestanian R. The effect of interactions on the cellular uptake of nanoparticles. Phys Biol. 2011; 8(4):046002. [PubMed: 21508440]

117. Peetla C, Labhasetwar V. Effect of molecular structure of cationic surfactants on biophysical interactions of surfactant-modified nanoparticles with a model membrane and cellular uptake. Langmuir. 2009; 25(4):2369-2377. [PubMed: 19161268]

118. Samani A, Plewes D. A method to measure the hyperelastic parameters of ex vivo breast tissue samples. Phys Med Biol. 2004; 49(18):4395-4405. [PubMed: 15509073]

119. Yang TH, Leung SK, Phipps S, Reuben RL, McNeill SA, Habib FK, Schnieder A, Stevens R. Invitro dynamic micro-probing and the mechanical properties of human prostate tissues. Technol Health Care. 2006; 14(4-5):281-296. [PubMed: 17065751]

120. Jalkanen V, Andersson BM, Bergh A, Ljungberg B, Lindahl OA. Indentation loading response of a resonance sensor-discriminating prostate cancer and normal tissue. J Med Eng Technol. 2013; 37(7):416-423. [PubMed: 23978075]

121. Shin TY, Kim YJ, Lim SK, Kim J, Rha KH. Robotic mechanical localization of prostate cancer correlates with magnetic resonance imaging scans. Yonsei Med J. 2013; 54(4):907-911. [PubMed: 23709425]

122. Ichinose, J.; Kohno, T.; Fujimori, S.; Harano, T.; Suzuki, S.; Fujii, T. Invasiveness and malignant potential of pulmonary lesions presenting as pure ground-glass opacities. Ann Thorac Cardiovasc Surg. 2013. http://dx.doi.org/10.5761/atcs.oa.13-00005

123. Nazarian A, von Stechow D, Zurakowski D, Muller R, Snyder BD. Bone volume fraction explains the variation in strength and stiffness of cancellous bone affected by metastatic cancer and osteoporosis. Calcif Tissue Int. 2008; 83(6):368-379. [PubMed: 18946628]

124. Plodinec M, Loparic M, Monnier CA, Obermann EC, Zanetti-Dallenbach R, Oertle P, Hyotyla JT, Aebi U, Bentires-Alj M, Lim RY, Schoenenberger CA. The nanomechanical signature of breast cancer. Nat Nanotech. 2012; 7(11):757-765.

125. Kim MS, Kim J, Lee W, Cho SJ, Oh JM, Lee JY, Baek S, Kim YJ, Sim TS, Lee HJ, Jung GE, Kim SI, Park JM, Oh JH, Gurel O, Lee SS, Lee JG. A trachea-inspired bifurcated microfilter capturing viable circulating tumor cells via altered biophysical properties as measured by atomic force microscopy. Small. 2013; 9(18):3103-3110. [PubMed: 23401221]

126. Sarna M, Zadlo A, Pilat A, Olchawa M, Gkogkolou P, Burda K, Bohm M, Sarna T. Nanomechanical analysis of pigmented human melanoma cells. Pigment Cell Melanoma Res. 2013; 26(5):727-730. [PubMed: 23647844] 


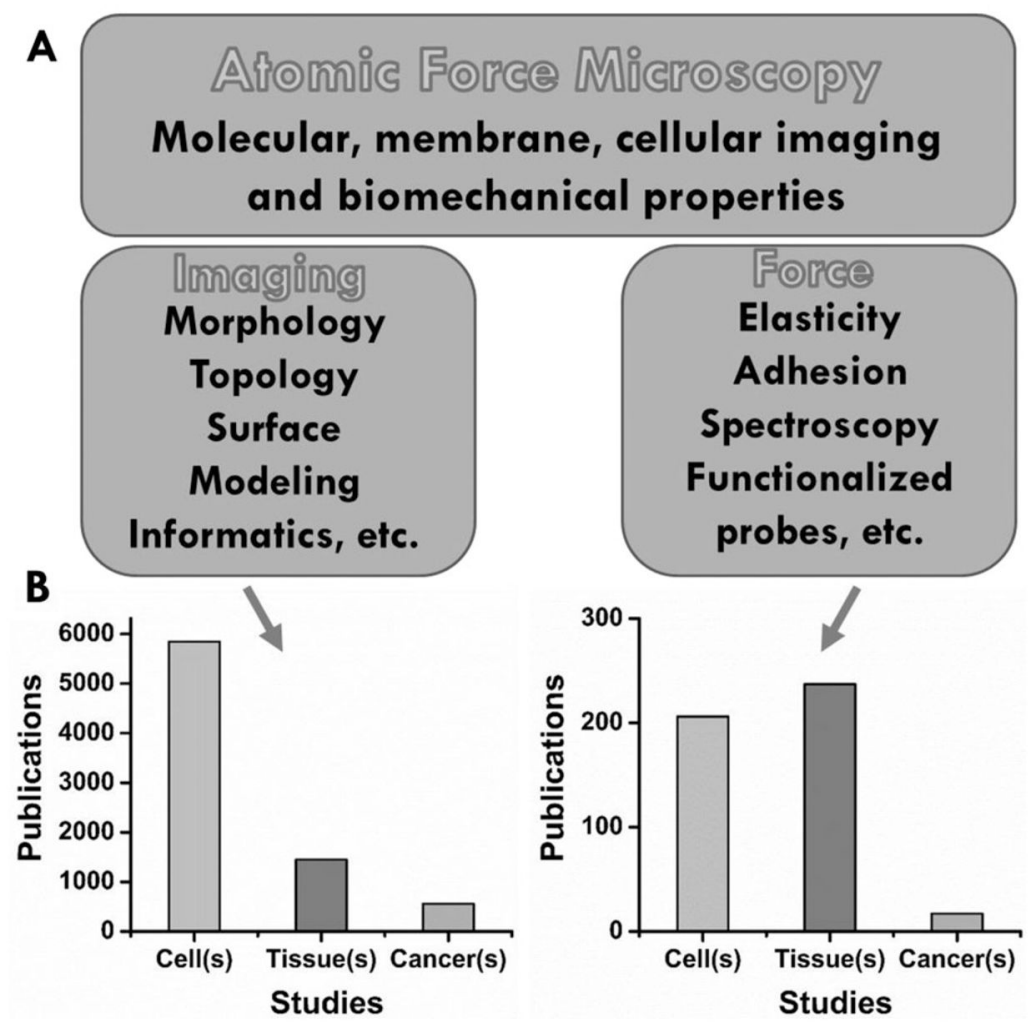

Figure 1.

Use of atomic force microscopy (AFM) in medicinal research. (A) AFM as a dual mode system for imaging and measuring force of cells and tissues at a nanoscale level. (B) Number of peer-reviewed publications using AFM for imaging and force (mechanical, nanomechanics, and nanoindentation) with cell(s), tissue(s), and cancer(s). Data collected using PubMed search (as of December 15, 2013) with key words: atomic force microscope (for imaging); and mechanical properties, biomechanical properties, nanomechanics, and nanoindentation (for force measurements). 

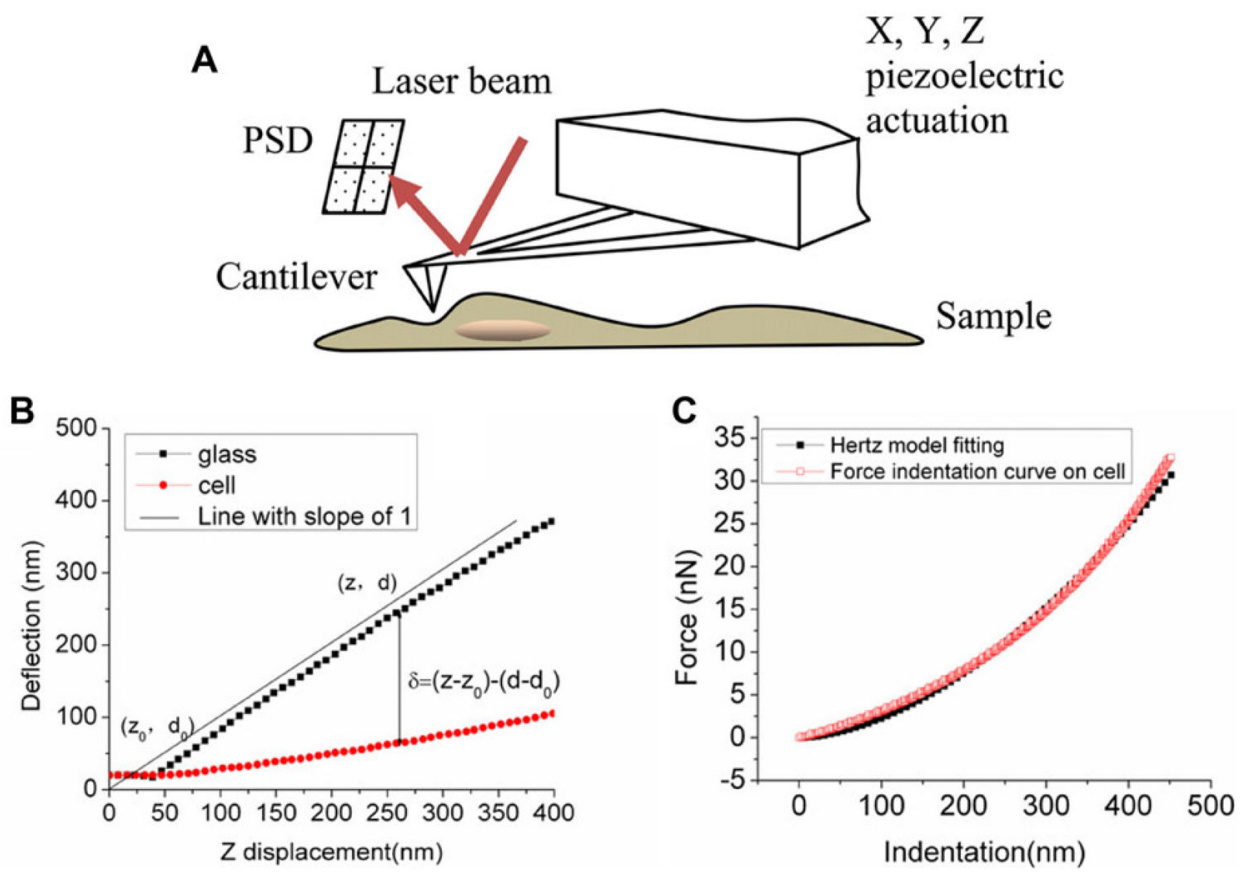

Figure 2.

(A) Schematic representation of imaging/nanoindentation of cells using atomic force microscopy and (B, C) the fitting of the force-indentation curve by Hertz model to generate the Young's modulus of cellular elasticity. Scheme and graphs in this figure are produced with special permission from 11 . 

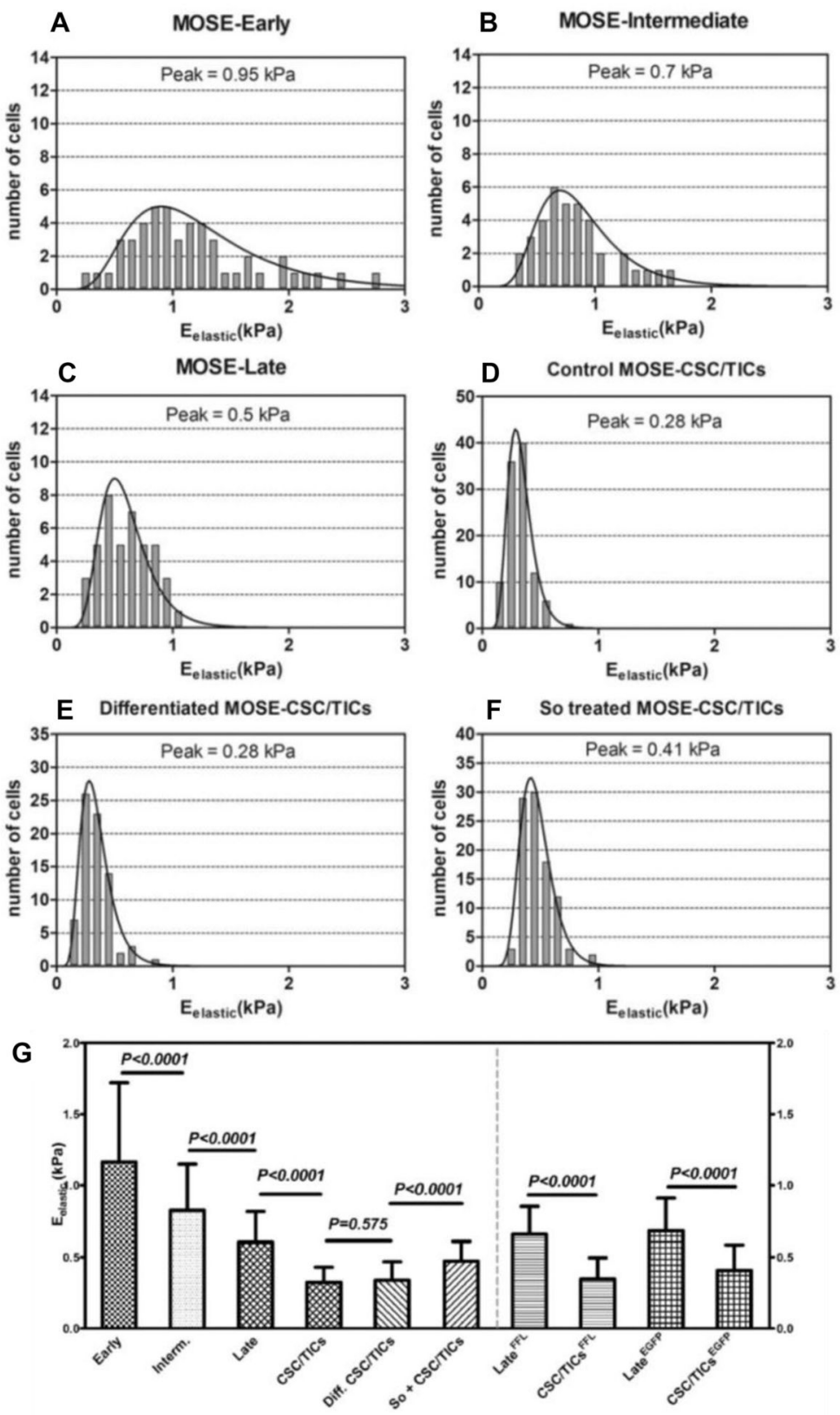

Figure 3.

Cell-elastic population distribution and elastic modulus of various stages of mouse ovarian surface epithelial (MOSE) and cancer cells. Population distribution responses of (A) early, (B) intermediate, (C) late MOSE cells and the MOSE cancer stem cells/tumor-initiating cells (CSC/TICs) in (D) control, (E) differentiated, and (F) treated conditions. (G) Elastic modulus of MOSE cancer cells and three variants of MOSE CSC/TICs. Note: The tumorinitiating phenotype matches well in the order of cancer malignancy-mechanics functionality profile. Graphs in this figure are reproduced with permission from 10. 


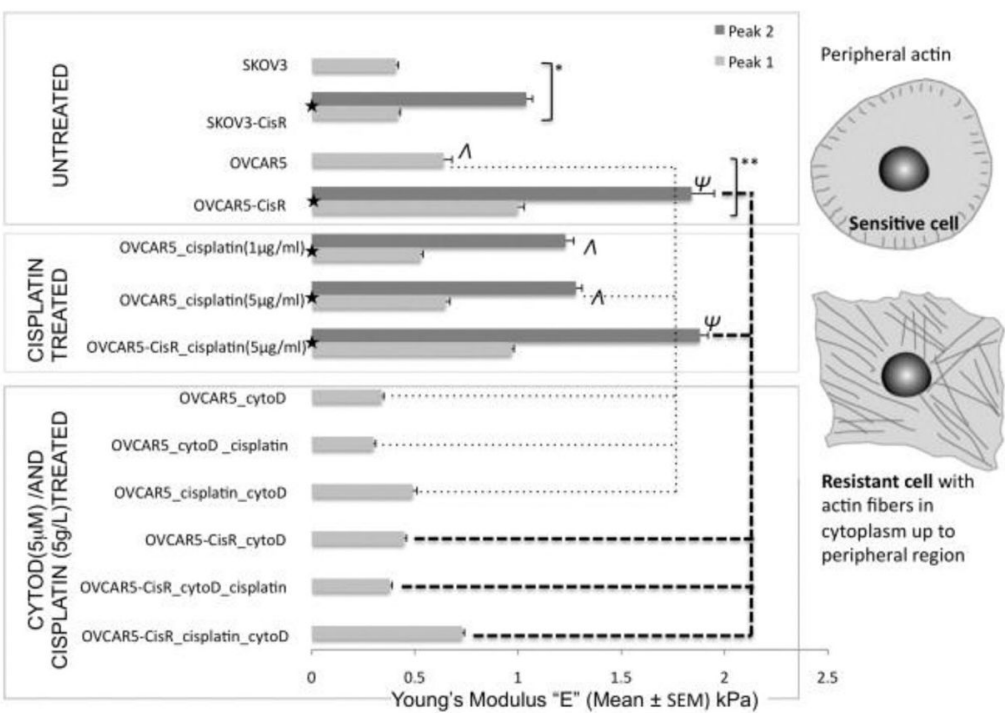

Figure 4.

Biomechanical profiles of cisplatin-sensitive and cisplatin-resistant ovarian cancer cells treated with cisplatin or cytod/cisplatin. Note: Data indicate cisplatin-induced increase in cell stiffness of OVCAR5 cells is mediated via actin cytoskeleton and disrupting the actin cytoskeleton with cytod treatment can reverse this cell stiffness. The graphs in this figure are reproduced with permission from 95 . 

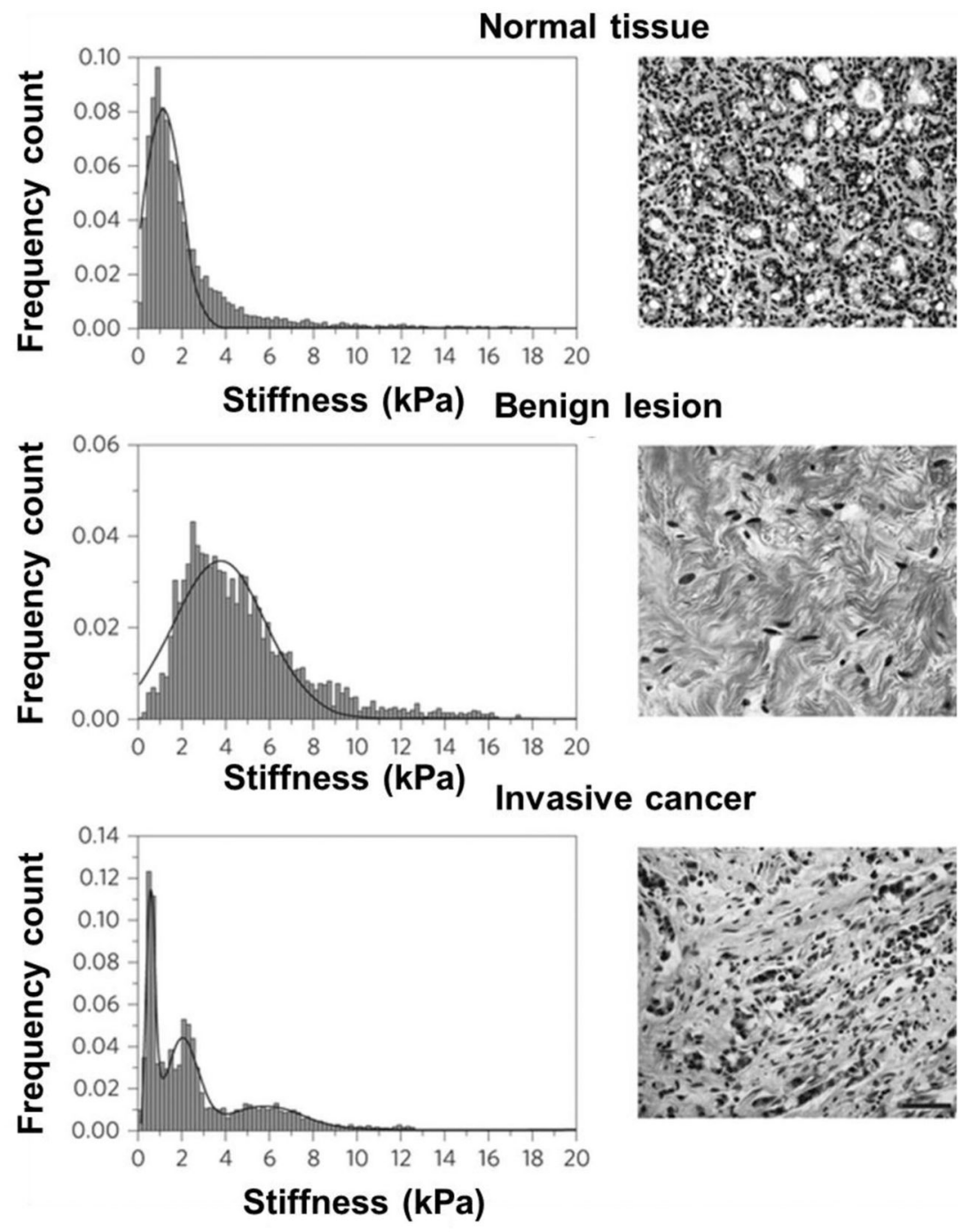

Figure 5.

Stiffness distribution for normal mammary gland tissue, benign lesion, and malignant tumor tissue is unimodal, unimodal but broader stiffness, and heterogeneous stiffness distribution with characteristic soft peaks, respectively. The H\&E-stained section confirms tissue identification for normal mammary gland tissue, benign lesion, and malignant tumor tissue. Scale bar applies to all images, $50 \beta \mathrm{m}$. Graphs in this figure are reproduced with permission from 124. 


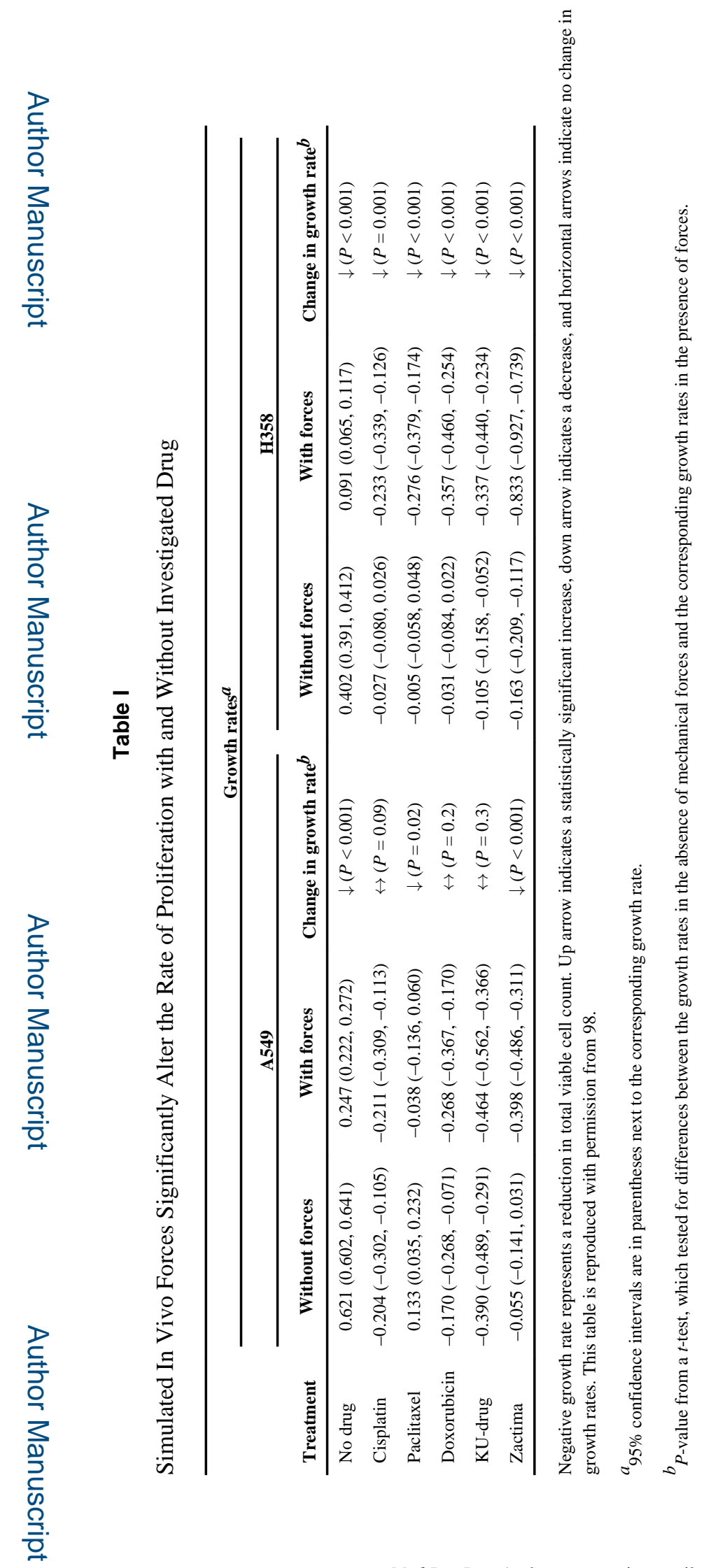

Med Res Rev. Author manuscript; available in PMC 2015 April 09. 


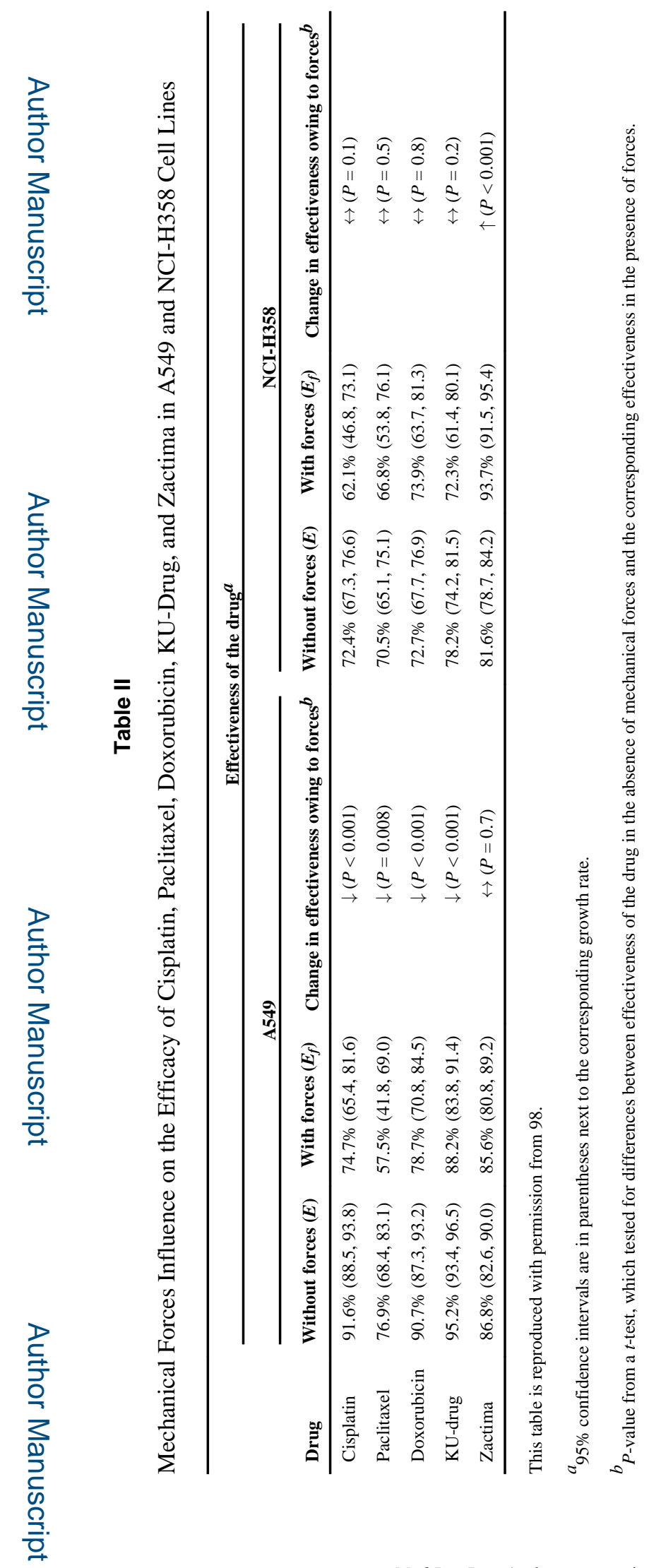

Med Res Rev. Author manuscript; available in PMC 2015 April 09. 